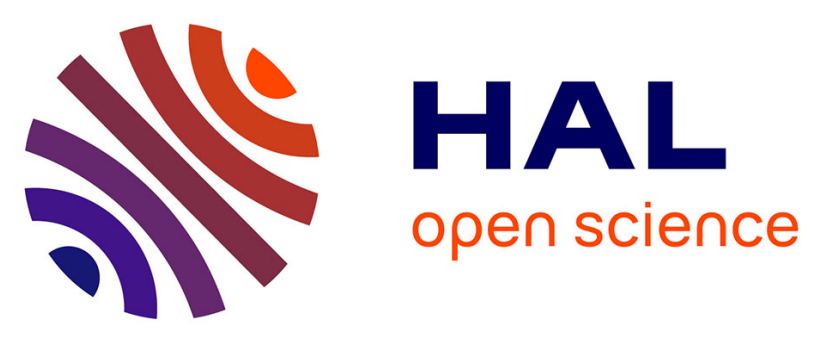

\title{
Nutrient inputs and hydrology together determine biogeochemical status of the Loire River (France): Current situation and possible future scenarios
}

Josette Garnier, Antsiva Ramarson, Gilles Billen, Sylvain Théry, Dominique Thiéry, Vincent Thieu, Camille Minaudo, Florentina Moatar

\section{To cite this version:}

Josette Garnier, Antsiva Ramarson, Gilles Billen, Sylvain Théry, Dominique Thiéry, et al.. Nutrient inputs and hydrology together determine biogeochemical status of the Loire River (France): Current situation and possible future scenarios. Science of the Total Environment, 2018, 637-638 (Octobre 2018), pp.609-624. hal-01792783v2

\section{HAL Id: hal-01792783 \\ https://hal.sorbonne-universite.fr/hal-01792783v2}

Submitted on 17 Dec 2018

HAL is a multi-disciplinary open access archive for the deposit and dissemination of scientific research documents, whether they are published or not. The documents may come from teaching and research institutions in France or abroad, or from public or private research centers.
L'archive ouverte pluridisciplinaire HAL, est destinée au dépôt et à la diffusion de documents scientifiques de niveau recherche, publiés ou non, émanant des établissements d'enseignement et de recherche français ou étrangers, des laboratoires publics ou privés. 


\title{
Nutrient inputs and hydrology together determine biogeochemical status of the Loire River (France): Current situation and possible future scenarios
}

\author{
Josette Garnier ${ }^{\mathrm{a}, *}$, Antsiva Ramarson ${ }^{\mathrm{a}}$, Gilles Billen ${ }^{\mathrm{a}}$, Sylvain Théry ${ }^{\mathrm{b}}$, Dominique Thiéry ${ }^{\mathrm{c}}$, Vincent Thieu ${ }^{\mathrm{a}}$, \\ Camille Minaudo ${ }^{\mathrm{d}}$, Florentina Moatar ${ }^{\mathrm{d}}$ \\ a Sorbonne Université - CNRS - EPHE, UMR 7619 Metis, BP 123, Tour 56-55, Etage 4, 4 Place Jussieu, 75005 Paris, France \\ b Sorbonne Université - CNRS - EPHE, FIRE-FR3020, BP 123, Tour 56-55, Etage 4, 4 Place Jussieu, 75005 Paris, France \\ ' BRGM, 3 avenue Claude-Guillemin, BP 36009, 45060 Orléans Cedex 2, France \\ d Université de Tours, EA 6293, Laboratoire GéoHydrosystèmes COntinentaux, Parc de Grandmont, 37200 Tours
}

\section{H I G H L I G H T S}

- Riverstrahler model was implemented on the Loire River for running scenarios.

- River eutrophication was reduced with better wastewater treatment.

- Alternative agro-food system systems would allow decreasing nitrate contamination.

- Climate change, reducing water flow, would increase river eutrophication.

\section{G R A P H I C A L A B S T R A C T}

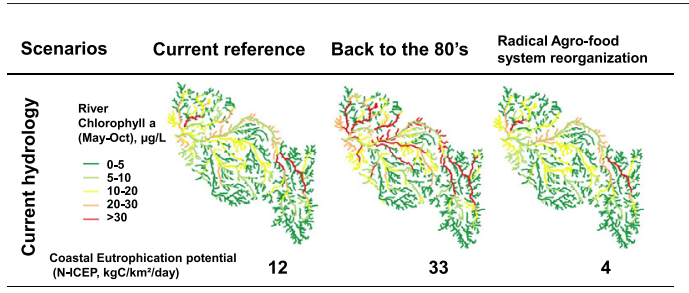

\section{A B S T R A C T}

The Grafs-Seneque/Riverstrahler model was implemented for the first time on the Loire River for the 2002-2014 period, to explore eutrophication after improvement of wastewater treatments. The model reproduced the interannual levels and seasonal trends of the major water quality variables. Although eutrophication has been impressively reduced in the drainage network, a eutrophication risk still exists at the coast, as shown by the N-ICEP indicator, pointing out an excess of nitrogen over silica and phosphorus. From maximum biomass exceeding $120 \mu \mathrm{gChla} \mathrm{l}^{-1}$ in the 1980's, we observed decreasing maximum values from 80 to $30 \mu \mathrm{gChla} \mathrm{l}^{-1}$ during the period studied.

Several scenarios were explored. Regarding nutrient point sources, a low wastewater treatment scenario, similar to the situation in the 1980 's, was elaborated, representing much greater pollution than the reference period (2002-2014). For diffuse sources, two agricultural scenarios were elaborated for reducing nitrogen, one with a strict application of the agricultural directives and another investigating the impact of radical structural changes in agriculture and the population's diet. Although reduced, a risk of eutrophication would remain, even with the most drastic scenario. In addition, a pristine scenario, with no human activity within the basin, was devised to assess water quality in a natural state. The impact of a change in hydrology on the Loire biogeochemical functioning was also explored according to the effect of climate change by the end of the 21st century. The EROS hydrological model was used to force Riverstrahler, considering the most pessimistic SRES A2 scenario run with the ARPEGE model. Nutrient fluxes all decreased due to a $>50 \%$ reduction in the average annual discharge, overall reducing the risk of coastal eutrophication, but worsening the water quality status of the river network.

The Riverstrahler model could be useful to help water managers contend with future threats in the Loire River, at the scale of its basin and at smaller nested scales.

\footnotetext{
* Corresponding author.

E-mail address: josette.garnier@upmc.fr (J. Garnier).
} 


\section{Introduction}

River water quality, biogeochemical functioning and fluxes of the transformation and transport of nutrients (phosphorus, nitrogen, silica) along the land-to-sea continuum depend on hydrology and human activities in watersheds. It is therefore necessary to take into account the various interactions between these major drivers to assess the ecological status of rivers. These interactions are similar for both past situations and the present, as well as the future when the impact of climate change will interfere with the anthropogenic pressures resulting from urban and agricultural activities (Ducharne et al., 2007).

Due to the complexity of these interactions, only a modeling approach can make the link between hydrology, anthropogenic land-based emissions and the resulting water quality. The Seneque/ Riverstrahler model was first developed for the Seine River $\left(75,000 \mathrm{~km}^{2}\right)$ within a 30-year long-term program (PIREN-Seine, Billen et al., 1994; Garnier et al., 1995; Ruelland et al., 2007) but simultaneously implemented for a variety of regional watersheds, including the Somme and the Scheldt rivers (Thieu et al., 2009; Passy et al., 2013), which differ in the size of their basin and their population density, the Kalix (Sferratore et al., 2008) and the Hong Rivers (Le et al., 2010, 2014), located in contrasting climates, cold and monsoon, respectively. The Seneque/Riverstrahler model has proved to be well adapted to examining the water quality of all of these rivers. Also, in order to explore water quality scenarios beyond the impact of point sources from wastewater treatment plants (WWTPs), a new approach, Grafs (Generalized Representation of the Agro-Food System), was coupled with the Seneque/Riverstrahler model, to determine agricultural scenarios by focusing on nitrate contamination, which is today a major problem in the drainage network in terms of producing drinking water for people (440 wells were closed in France between 1998 and 2008, Direction Générale de la Santé, 2012) and for preserving biodiversity (vegetal, James et al., 2005; and animal, Camargo et al., 2005). At the coastal zone, excess nutrients delivered by the river (especially nitrate) lead to eutrophication and harmful algal blooms, both potentially damaging for various economic activities (Justić et al., 1995; Billen and Garnier, 1997; Cugier et al., 2005; Heisler et al., 2008; Viaroli et al., 2008; Lancelot et al., 2011; Howarth et al., 2011; Davidson et al., 2014; Passy et al., 2016).

In this paper, the objective was to explore scenarios for further improving the water quality of the Loire River, although eutrophication has been considerably reduced in the past two decades (Minaudo et al., 2015, 2016). The Loire Basin is an intensive agricultural basin, mainly in its central sector as a part of the rich loamy soils of the Paris basin (Beauce region), with nitrate contamination of surface waters and the associated problem mentioned above (Dupas et al., 2013; Poisvert et al., 2017). Also, the Middle and Lower Loire River are highly sensitive to eutrophication because multiple channels and the pattern of sandbars, combined with a low water level in summer, increase water residence time and water temperature (Moatar and Gailhard, 2006; Latapie et al., 2014). In the 1980's, the Loire was highly eutrophic, with chlorophyll peaks exceeding $120 \mu \mathrm{gl}^{-1}$ for 3 months in summer (Crouzet, 1983), daily dissolved oxygen variations up to $12 \mathrm{mg} \mathrm{l}^{-1}$ and $\mathrm{pH}$ reaching 10 units (Moatar et al., 1999, 2001).

The Seneque/Riverstraher model was therefore newly implemented on this second largest watershed in France. We elaborated agricultural scenarios to be compared with the reference period, taken from 2002 to 2014 , to assess the extent to which changing agriculture can be used as a lever for improving water quality. Also, considering the strong decrease in discharge predicted by the climate scenario, we examined the impacts induced by a change in hydrological regimes on the biogeochemical behavior of the Loire River.

\section{Study site and methods}

\subsection{The Loire River}

The Loire River basin is one of the largest of the North Atlantic coast line $\left(117,045 \mathrm{~km}^{2}\right)$. The source of the Loire River is located at Le Mont Gerbier-de-Jonc (elevation, $1412 \mathrm{~m}$ ), southeast of the Massif Central mountains. The mean annual water flow is $830 \mathrm{~m}^{3} \mathrm{~s}^{-1}$ at the Montjean-sur-Loire outlet of the catchment, with an average flow of $1540 \mathrm{~m}^{3} \mathrm{~s}^{-1}$ in February and $250 \mathrm{~m}^{3} \mathrm{~s}^{-1}$ in August, with already observed irregular flood events up to $7000 \mathrm{~m}^{3} \mathrm{~s}^{-1}$ and dry periods with about $20 \mathrm{~m}^{3} \mathrm{~s}^{-1}$ in the Middle Loire (200 km upstream of Montjeansur-Loire), (Table 1 ).

The Loire River is less managed than the other large French rivers, although two major reservoirs slightly modify its flow in the Upper Loire (Grangent: Latour et al., 2004; Villerest: Bonnet et al., 2000).

Due to its wide watershed, the hydroclimatic characteristics of the Loire Basin range from humid mountains to temperate oceanic. The population density is rather low from 50 inhabitants. $\mathrm{km}^{-2}$ to 150 inhab. $\mathrm{km}^{-2}$ in the downstream sector (63.6 inhab. $\mathrm{km}^{-2}$ on the whole in 2015). The Loire Basin's main stem comprises three major cities (Orléans, Tours and Angers, from 400,000 to 500,000 inhab., including their agglomeration), in addition to Nantes located on the estuary with 870,000 people, including the whole conurbation. Land occupation comprises $30 \%$ arable area (mostly in the central part of the Loire basin), $42.3 \%$ grassland and $23.7 \%$ forest, the remaining being urban zones (3.5\%) and surface water and wetlands ( $0.5 \%)$, (Table 1$)$. To analyze the results of the modeling approach, the Loire can be split into one major axis from the confluence of the Loire and Allier rivers and seven sub-basins (Upstream Loire, Allier, Cher, Indre, Vienne, Thouet and Maine rivers), although the resolution of the model was more detailed (Fig. 1 and see below).

\subsection{Implementing Seneque/Riverstraher on the Loire River}

\subsubsection{The biogeochemical model}

Riverstrahler calculates spatial and temporal variations of the discharge and water quality (nutrients), taking into account a generic representation of ecological functioning for the whole hydrographic network, as a function of the constraints given by the morphology of

Table 1

General characteristics of the Loire River for the period studied (2002-2014).

\begin{tabular}{|c|c|c|}
\hline General characteristics of the Loire River (2002-2014) & Units & Values \\
\hline Surface area at Montjean-sur-Loire (including the estuary) & $\mathrm{km}^{2}$ & $110,518(117,045)$ \\
\hline Elevation at the source & $\mathrm{m}$ & 1412 \\
\hline Mean annual flow at Monjean-sur-Loire (min and max montly means) & $\mathrm{m}^{3} \mathrm{~s}^{-1}$ & 830 (250 in August-1540 in February) \\
\hline Total population at Montjean-sur-Loire (including the estuary) & Inhabitants & $6,855,230(7,441,102)$ \\
\hline Mean population density at Montjean-sur-Loire (including the estuary) & Inhabitants. $\mathrm{km}^{-2}$ & $62(63.6)$ \\
\hline Cropland area & $\%$ & 30.0 \\
\hline Grassland area & $\%$ & 42.3 \\
\hline Forest & $\%$ & 23.7 \\
\hline
\end{tabular}




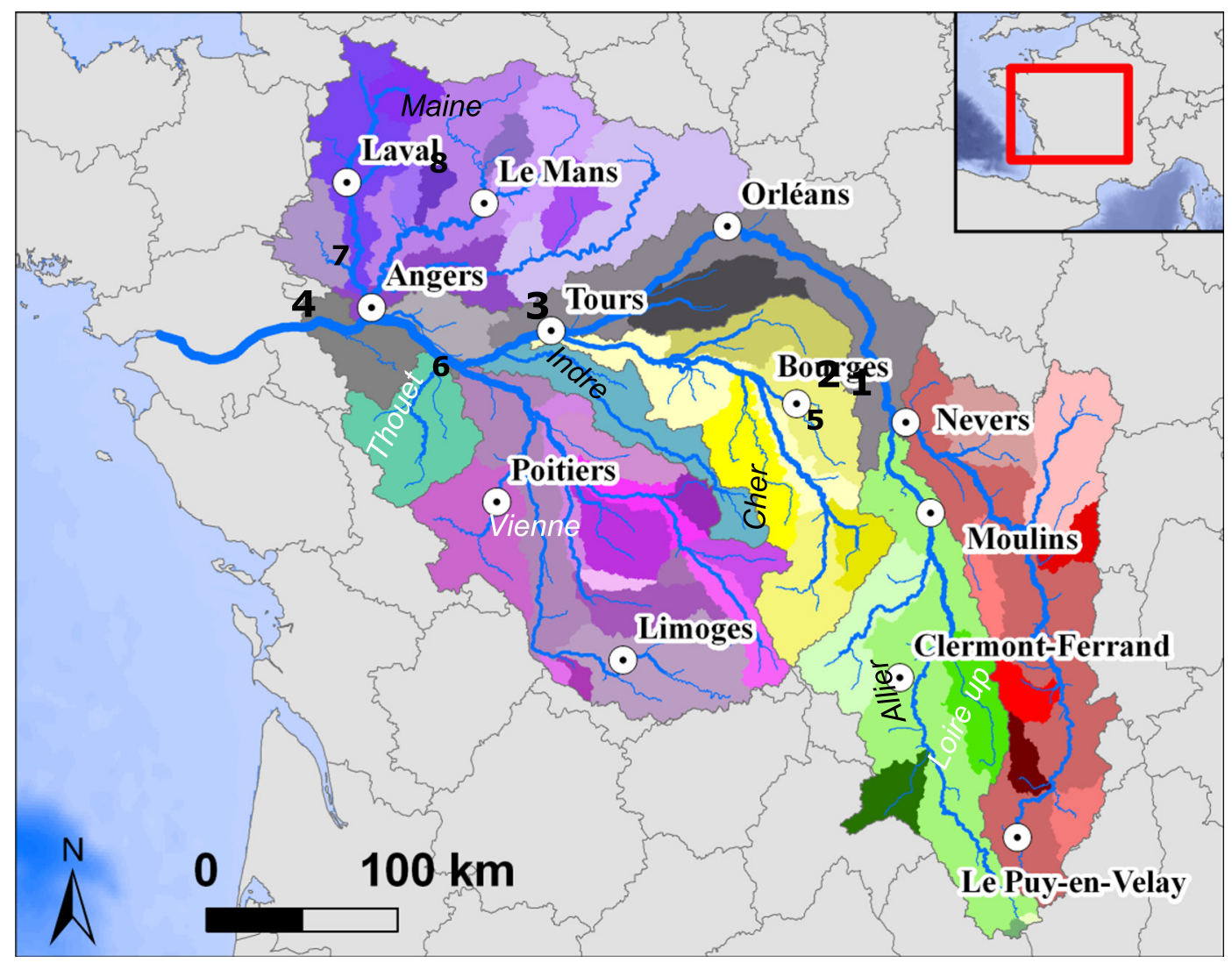

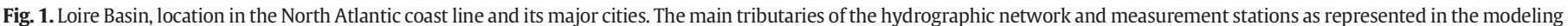
approach and hydrographic network are also indicated: numbers $1-4$, stations on the course of the Loire; $5-8$, stations of major sub-basins.

the drainage network (e.g., length and depth of the rivers), the meteorological and hydrological conditions, as well as the inputs related to land use (diffuse sources) and from domestic urban and industrial wastewater (point sources) (Fig. 2). Seneque is the software in which the Riverstrahler model is imbedded into a GIS environment (Ruelland et al., 2007).

\section{GRAFS}

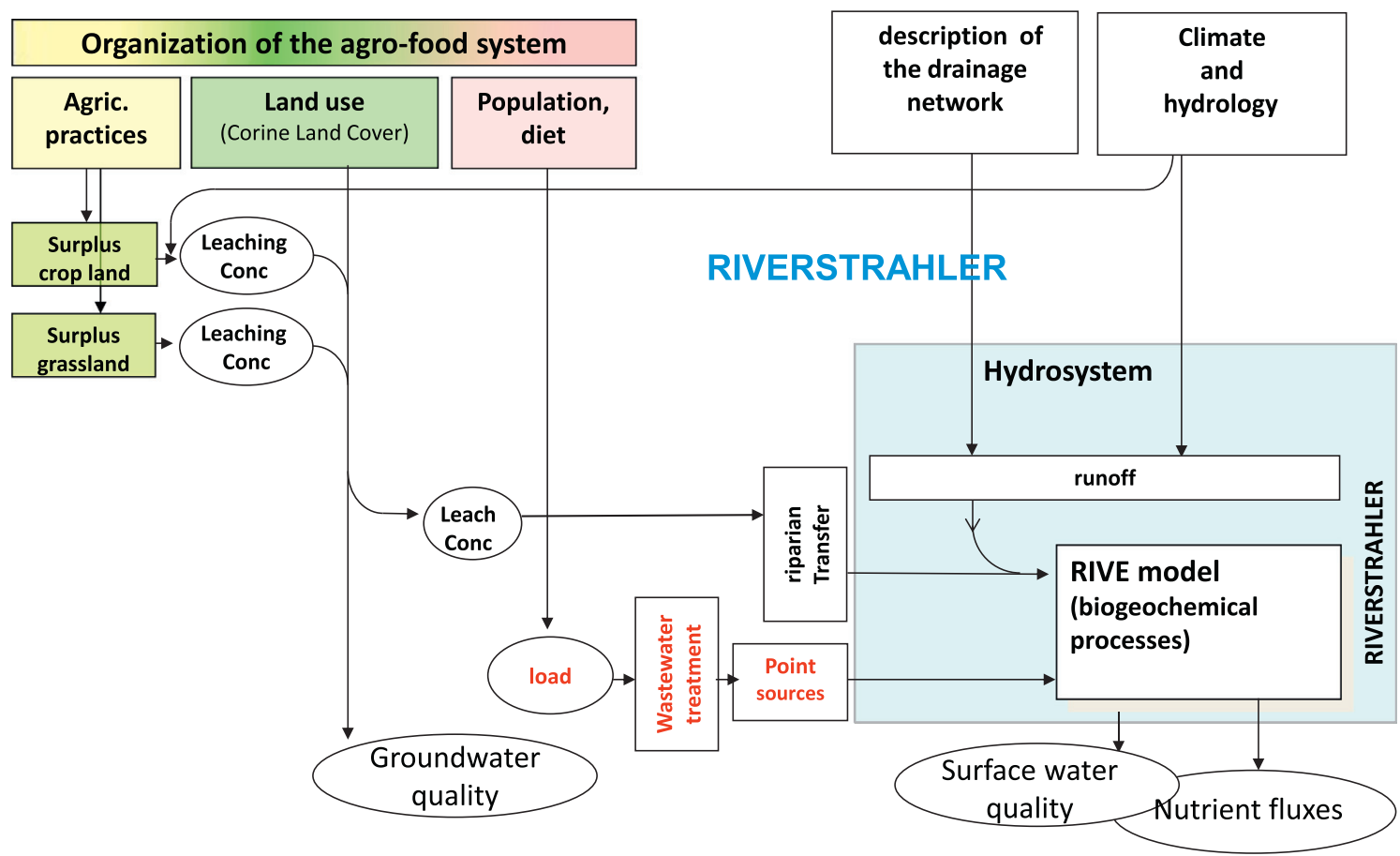

Fig. 2. Representation of the principles of the Grafs-Seneque-Riverstrahler modeling approach. 
The module representing biogeochemical functioning (namely RIVE, www.fire.upmc.fr/rive) takes into account three compartments of phytoplankton, two compartments of bacteria and two compartments of zooplankton. RIVE also takes into account the transformation of major nutrients $(\mathrm{Si}, \mathrm{P}, \mathrm{N})$ and calculates oxygen and carbon concentrations in the water column and at the water/sediment interface, on a seasonal scale.

The three compartments of phytoplankton mathematically formalized in the RIVE module are the Diatoms, the Chlorophyceae and the Cyanobacteria, which often dominate in freshwater systems. Unlike stagnant systems, river waters are not favorable for Cyanobacteria growth, which can, however, be brought to the rivers in communication with ponds, reservoirs, dead arms, etc. Phytoplankton dynamics (growth, mortality, excretion, grazing) have been described previously (Lancelot et al., 1991; Garnier and Billen, 1993; Garnier et al., 1998). The model comprises 30 variables for which the kinetics of transformations and parameter values have been described in Garnier et al. (2002). As kinetics and parameters of the processes were independently determined, and not adjusted by calibration, the comparison between simulations and observations represents a true validation of the model. The calculation time step is $10 \mathrm{~min}$, but the time resolution of the results provided is 10 days.

\subsubsection{Representation of the hydrographic network}

The structure of the Seneque GIS framework requires a detailed description of the hydrographic network for which we identify the elementary basins (EBs) with their own characteristics (slope, width, length) within the upstream-downstream scheme of river confluences. This structuring of the Loire River's drainage network was obtained from the IGN database (CarTHAgE®) and from an elevation model (50 m, http://professionnels.ign.fr/bdalti) (Fig. 1). A total of 5226 EBs were considered.

\subsubsection{Model inputs}

2.2.3.1. Hydrology. Hydrological data are those provided by the HYDRO database (http://www.hydro.eaufrance.fr), averaged at a daily time step and then broken down into surface runoff and base flows, using the Bflow recursive filter (Lyne and Hollick, 1979; Arnold and Allen, 1999 for the method and informatics program, respectively). Surface runoff and base flows were generated using observed discharge time series at 63 gauging stations for the 2002-2014 period, for each elementary sub-basin and main stems considered for the modeling project (here 42 sub-basins and 12 main stems). These basins were then grouped by large tributaries with the Loire River valley as a main stem (Fig. 1).

To explore the role of hydrology under climate change on the biogeochemical behavior of surface water, we selected the most pessimistic climatic scenario (i.e., the highest expected $\mathrm{CO}_{2}$ emission increase) among the many calculated (Moatar et al., 2010) in terms of discharge perturbations (here a strong decrease) coming from the hydrological model EROS (BRGM) (Thiéry, 2018). Ten years (2090-2100) of EROS-simulated runoffs resulting from the ARPEGE GCM (General Circulation Model, Déqué et al., 1994) runs forced by the SRES A2 scenario, were chosen within the 2047-2100 period, because it includes a succession of wet and dry years, similar to the reference period studied (2002-2014). For this reference period, EROS used atmospheric variables near the surface from the SAFRAN mesoscale analysis system. The two components of the discharge required by Riverstrahler are those provided by EROS for the 42 sub-basins and 12 main stems considered under the reference and climatic scenarios. Changes in temperature were not taken into account here.

2.2.3.2. Point sources. The water agency (Agence de l'Eau Loire-Bretagne, AELB) provided the domestic effluents for the years 2002 (used for the 2002-2005 period) and 2010 (used for the 2006-2010 period), which were all spatially explicitly implemented in the model (Fig. 3a). From 2011 to 2014, data were extracted from the municipal sanitation information portal (http://assainissement.developpement-durable.gouv.fr/). However, for the ten largest wastewater treatment plants (Angers, Le Mans, Tours, Orléans, Bourges, Limoges, Clermont-Ferrand, Roanne and Vichy), a year-by-year update was carried out from the portal cited above. The total amount of collected effluent represents between 6,447,597 and 9,715,769 inhabitant equivalents (inhab. equ.), Table 2). The discharged effluents were evaluated in terms of phosphorus $(\mathrm{P})$ and nitrogen $(\mathrm{N})$ from the specific treatment of each wastewater treatment plant (WWPT). These changes in specific treatments were selectively applied for the 2002-2014 period (see Table 2).

For industrial point sources, we used the data provided by AELB (2006 data used for 2002-2006; 2012 data used for 2007-2012, and average corresponding data for 2013-2014, included in Table 2).

2.2.3.3. Diffuse sources. The Seneque/Riverstrahler model requires documenting the concentrations of all water quality variables taken into account for the two components of the discharge (surface runoff and base flows).
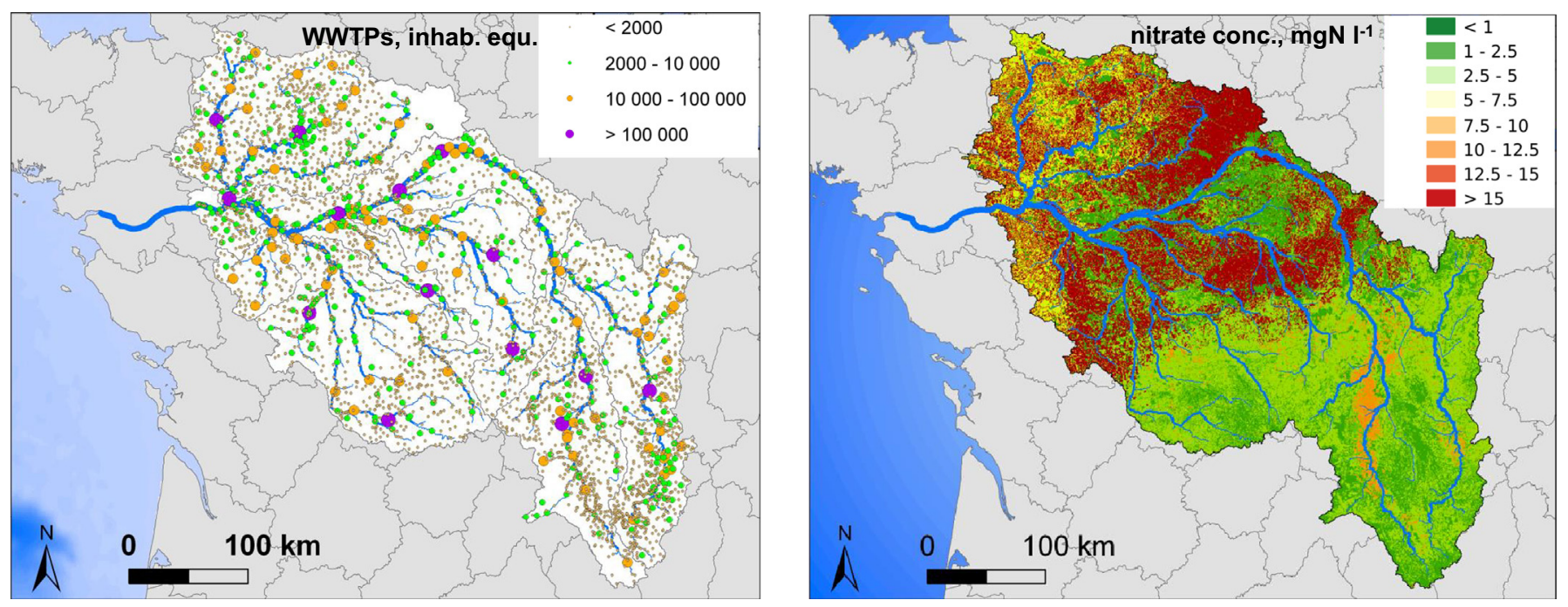

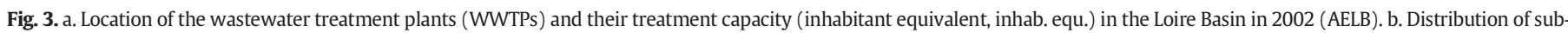
root water nitrate concentrations $\left(\mathrm{mgN}^{-1}\right)$ calculated for the Loire basin, based on data on land cover and agricultural practices. 
Table 2

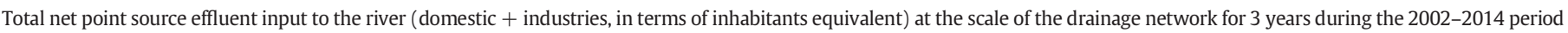

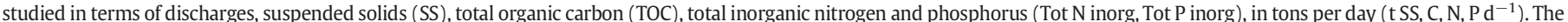
fraction of ammonium to total inorganic nitrogen ( $\mathrm{N}-\mathrm{NH} 4, \%)$ is indicated, showing the increase in denitrification in the wastewater treatment (i.e., decreased $\mathrm{N}-\mathrm{NH} 4)$.

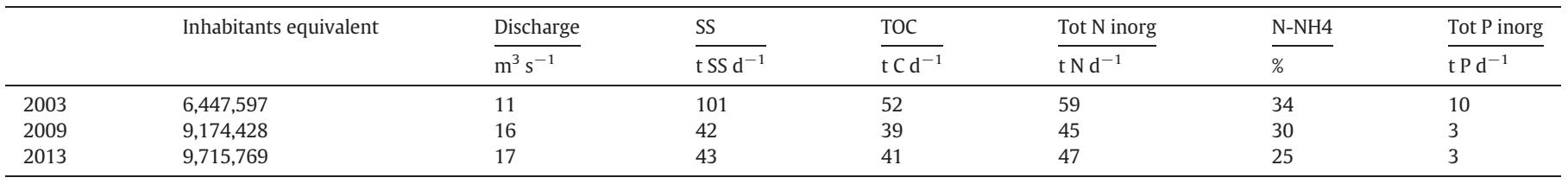

The approach used for nitrogen is the most sophisticated, because the diffuse sources of this element are dependent on the structure of the agro-food system of the areas composing the watersheds. The major land use classes (cropland, permanent grassland, forests, urbanized areas) were spatially determined using the Corine Land Cover database (Bossard et al., 2000; EEA, 2007) (Fig. 3b). The GRAFS approach (Billen et al., 2014; Le Noë et al., 2017; see Fig. 2) was then used to calculate, from regional agricultural statistics at the "département" level (Nuts 3), nitrogen leaching flux and concentrations (Anglade et al., 2017; Anglade, 2015), for both surface runoff and base flow, for each land use class.

Other diffuse sources of suspended solids are derived from PESERA estimates of soil erosion (Kirkby et al., 2004) and combined with topsoil data from the European LUCAS survey (Toth et al., 2013) to estimate land-based emissions of particulate phosphorus and organic carbon. Dissolved silica concentrations are assigned according to lithomorphological information (European Ecoregions: Wasson et al., 2004) using a simple dichotomy between crystalline and sedimentary rocks (3.6 $\mathrm{mg} \mathrm{Si} \mathrm{L}^{-1}$ for sedimentary rocks or recent alluviums and $7 \mathrm{mg} \mathrm{Si} \mathrm{^{-1 }}$ for crystalline or metamorphic rocks, in accordance with the value provided by Meybeck, 1986).

\subsection{Validation of the model}

The kinetics of the processes and the parameters were determined independently either from our own experiments or from the literature (see Garnier et al., 2002), and are a priori defined. Therefore the comparison between the simulations and observations represents the reliability of the model. Disagreement may be the result of (i) uncertainties regarding constraints and observations or (ii) incomplete understanding of the ecosystem functioning.

Water flow and water quality data (nitrate, ammonium, phosphates, total phosphorus, silica and chlorophyll $a$ ) were gathered from the Loire-Bretagne Water Agency surveys (2002-2014), available at intervals ranging from monthly to every 2 months (http://osur.eau-loirebretagne.fr/exportosur/Accueil).

We chose the Montjean-sur-Loire station for a validation at the outlet of the Loire and the entrance of the Loire estuary, the upstream limit of the dynamic tide (see Fig. 1). We also validated the model along the Loire River, and at the outlet of the major tributaries, i.e., seven additional stations (see Fig. 1).

Two indexes of the goodness of fit of the model simulations were calculated: the normalized range of the observations (NRMSE, i.e., a percentage of variation) and the slope of the regression line, forced to zero intercept, between the simulated and observed values (Table 3).

\section{Results}

\subsection{Interannual variations of water flow and quality}

\subsubsection{Water flow}

Despite the 10-day time resolution of the hydrological calculations, the observed and calculated variations of the data agreed well. The 2002-2014 average discharge at the outlet was $830 \mathrm{~m}^{3} \mathrm{~s}^{-1}$ with e.g., wet (2013: $\left.1219 \mathrm{~m}^{3} \mathrm{~s}^{-1}\right)$ and dry years $\left(2011: 457 \mathrm{~m}^{3} \mathrm{~s}^{-1}\right)$. On the seasonal scale, summer low water can fall below $150 \mathrm{~m}^{3} \mathrm{~s}^{-1}$ and winter high water exceeded $4000 \mathrm{~m}^{3} \mathrm{~s}^{-1}$ (see Fig. 4). Typically the lowest waters were observed from mid-July to the end of October.

NRMSE and slope indicators for discharge at the eight stations over the 2002-2014 period showed very good agreement between calculations and observations (Table 3 ).

\subsubsection{Water quality variables}

NRMSE was $<20 \%$ for nitrate, ammonium, silica and suspended solids, and reached $25-28 \%$ for phosphorus and chlorophyll (Table 3 ), showing that the levels of values were similarly reproduced for the different variables. However, the slope indicated an overestimation for nitrate and phosphorus and an underestimation for suspended solids and chlorophyll $a$, and a lesser underestimation for silica (Table 3).

Variations in nitrate concentrations at Montjean-sur-Loire, the receptacle of all tributaries of the Loire River, represent the integration of all inputs, transfers and transformations within the drainage network. Simulations of nitrate concentrations fit rather well with the observations, both in terms of seasonal and interannual variations (Fig. 5). Whereas a drop in nitrate $\left(\mathrm{NO}_{3}\right)$ systematically occurred from spring to the end of summer, leading to ample variations in concentrations (2-7 mg N-NO $\mathrm{N}_{3} \mathrm{~L}^{-1}$ ) explained mostly by riparian denitrification, interannual variations were linked to the discharge, with nitrate originating from diffuse sources. Ammonium $\left(\mathrm{NH}_{4}\right)$, phosphates $\left(\mathrm{PO}_{4}\right)$ and total phosphorus (TP), known to mostly come from point sources, had opposite seasonal variations, with a dilution by high winter discharges and an increased concentration during summer at low river water, because the volume of discharged treated effluent remained rather stable throughout the year. Year-to-year variations showed a decrease in these point source variables, after a full implementation of the EU-UWWD (1991) and EU-WFD (2000). Regarding phytoplankton biomass, expressed in terms of chlorophyll $a$ concentrations, a decrease was observed related to improvement in phosphorus concentrations, from 2008 onwards. Even though the seasonal dynamics were not always adequately described, the general interannual trend was reproduced with an underestimation mainly in the early period of the study (Fig. 5). Dissolved silica concentrations varied in the opposite direction compared

\section{Table 3}

Evaluation of the Seneque-Riverstrahler performance for the Loire River. The goodness of fit of the simulations with respect to the observed concentration values at 8 the selected stations (cf. Fig. 4) was evaluated for the major variables of water quality by calculating the root mean square error, normalized to the range of the observed data (NRMSE), according to the formula (NRMSE $=100 * \mathrm{SQR}\left(1 / \mathrm{n}_{\mathrm{l}}\left(\mathrm{Obs}_{\mathrm{i}}-\mathrm{Sim}_{\mathrm{i}}\right)^{2}\right) /\left(\mathrm{MAX}(\mathrm{Obsi})-\mathrm{MIN}\left(\mathrm{Obs}_{\mathrm{i}}\right)\right)$ where $n$ is the number of observations $\left.\mathrm{Obs}_{\mathrm{i}}\right)$. The NRMSE represents a percentage of variation, whereas the slope of the regression line between simulated (Sim) and observed (Obs) values indicates an over- or underestimation.

\begin{tabular}{llll}
\hline Variables & Observations (n) & \% NRMSE & $\begin{array}{l}\text { Slope, Sim vs. Obs } \\
\text { (dimension less) }\end{array}$ \\
\hline Discharge & 29,257 & 3 & 1 \\
Nitrate & 1047 & 14 & 1.2 \\
Ammonium & 1048 & 10 & 0.5 \\
Total P & 1045 & 26 & 1.5 \\
Phosphates & 1047 & 28 & 1.5 \\
Dissolved silica & 757 & 14 & 0.9 \\
Chlorophyll a & 613 & 25 & 0.5 \\
\hline
\end{tabular}



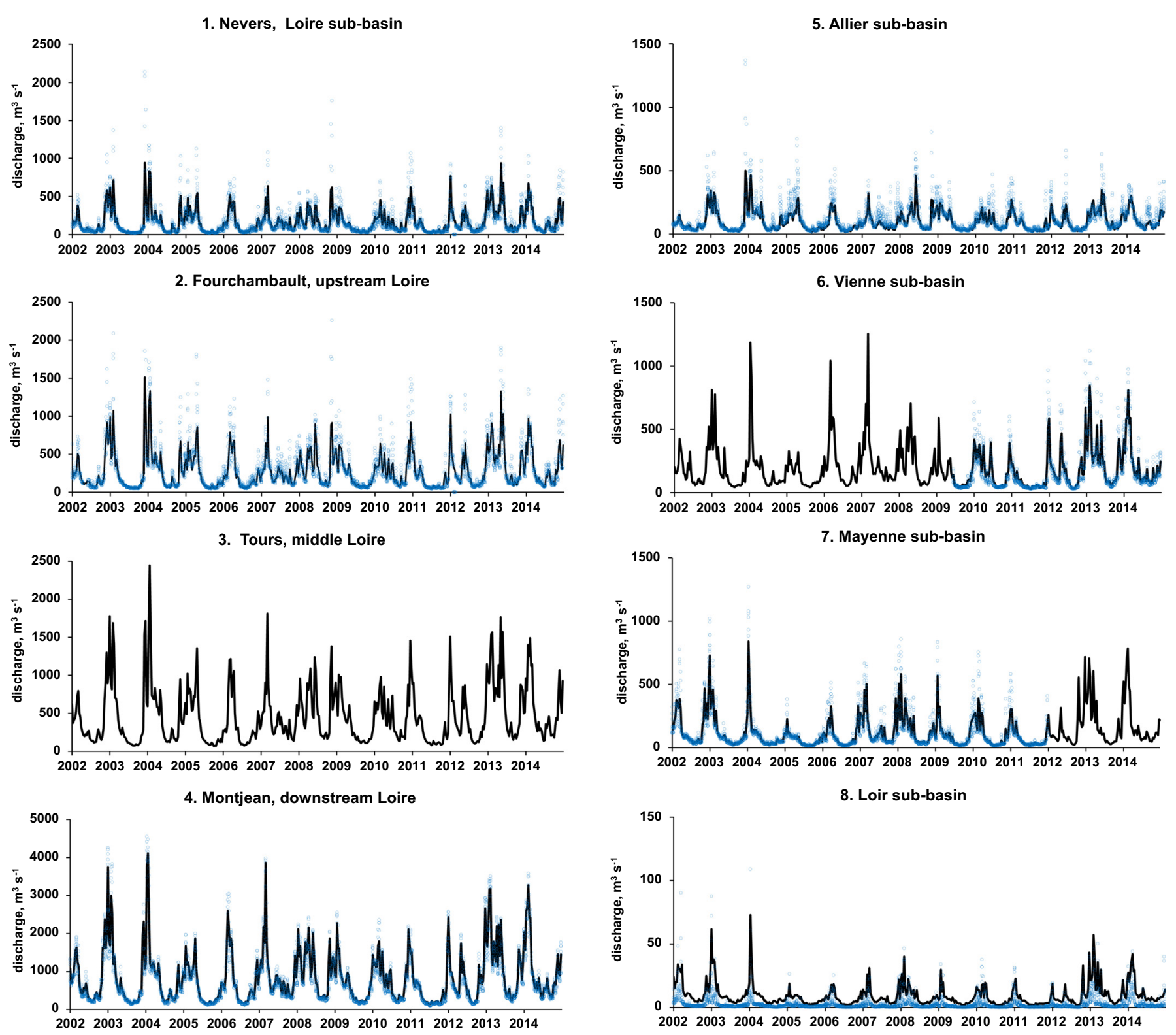

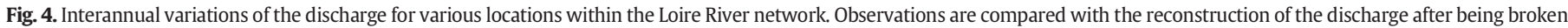
down into surface and base flows, using the BFlow recursive filter.

to algal biomass, because major blooms in rivers are made up of diatoms that consume silica to build their frustule, which was correctly represented by the model (Fig. 5 and SM1).

The Riverstrahler model, with its new module for riparian denitrification (Billen et al., 2018) is able to catch both the winter maximum level of nitrate concentration in the different sectors of the basin with contrasting land use, and their seasonal variations with strongly reduced concentrations in summer. This new approach used a single adjustable parameter representing the potential denitrification rate of wetland soils. The results pointed out the importance played by these riparian systems in decreasing nitric contamination coming from agricultural lands.

The same samples of locations as for Fig. 4 were chosen along the major stem of the river (Fig. 6, left) and certain tributaries with different land use from upstream to downstream (Fig. 6, right). As shown in Fig. 3, the distribution of nitrate sub-root concentrations evidenced a strong water contamination (ground- and surface water) due to intensive cereal cropping in the middle and downstream part of the basin.
Whereas nitrate surface concentrations peaked at $2 \mathrm{mgN}-\mathrm{NO}_{3} \mathrm{l}^{-1}$ in the upstream basin (Upstream Loire and Allier rivers), concentrations more than doubled in the downstream part, and reached up to the threshold value for drinking water production $\left(11 \mathrm{mgN}-\mathrm{NO}_{3} \mathrm{l}^{-1}\right)$ in the most intensively cropped Beauce Region (e.g., the Loir catchment embedded in the Mayenne sub-basin).

\subsubsection{Nutrient deliveries to the Loire estuary and their ratios}

Nutrient fluxes at the estuarine zone showed a large variation depending on the hydrological year, higher by a factor of 2.9 and 2.4 for phosphorus and nitrogen, respectively, and 3 for silica when discharge varied by a factor of 2.7 between the driest (2011) and wettest (2013) years (Table 4 ).

The indicator of coastal eutrophication potential, N- and P-ICEP (Billen and Garnier, 2007) is based on the C:N:P:Si molar ratios of 106:16:1:42 (Redfield et al., 1963; Conley et al., 1989). ICEP can be positive or negative and represents the excess or the deficit of either $\mathrm{N}$ or $\mathrm{P}$, respectively, over silica. Silica is essential for diatom growth stemming 

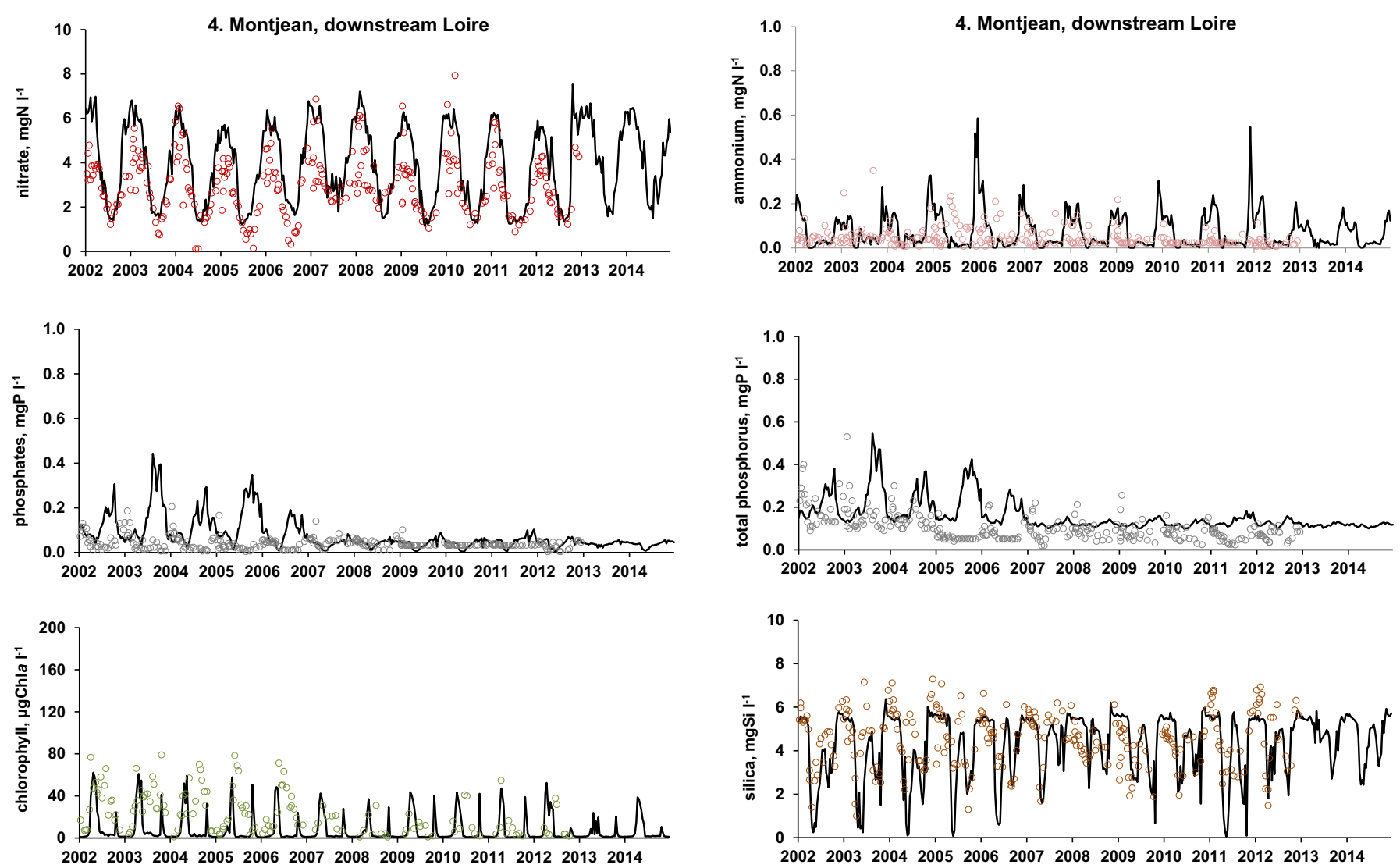

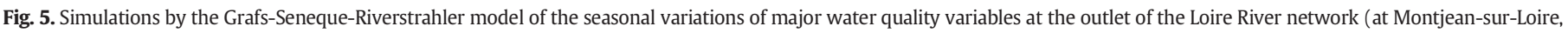
namely Montjean). Comparison with observations for nitrate, ammonium, phosphates, total phosphorus, chlorophyll $a$ and silica.

from natural rock weathering, differently from anthropogenic inputs of $\mathrm{N}$ and $\mathrm{P}$. Whereas the nitrogen flux largely exceeded the silica flux $(\mathrm{N}-$ ICEP $>0$ ), P-ICEP did not reveal any silica deficit for diatom development (P-ICEP $<0$ ), (Table 4). Importantly, this nutrient imbalance of nitrogen fluxes at the coastal zone has been shown to determine the succession of diatoms by non-diatoms, potentially toxic algae (Tilman et al., 1982).

\subsection{Exploring possible future scenarios for the Loire Basin}

\subsubsection{Role of wastewater treatments}

Because the implementation of the Urban Wastewater Treatment Directive (UWWTD EU Directive, 1991) prescribing tertiary treatment of nitrogen and phosphorus in wastewater treatment plants is now near completion and has considerably improved phosphorus levels in the Loire River, we explored a scenario for showing the effect of a lower level of treatment in WWTPs, as was the case in the 1980's. Only standard activated sludge treatment was considered for cities above 2000 inhab. equ., while smaller towns were considered to discharge their wastewater without any treatment (Fig. 7). Therefore in this low treatment scenario, 30-40\% the total nitrogen and phosphorus load remained untreated.

We also elaborated a theoretical "pristine" scenario assuming no human activity in the watershed, considered entirely covered by forest (Desmit et al., 2018). This scenario provides a baseline corresponding to the natural background of nutrient concentrations.

The highest differences in fluxes were observed for nitrogen, with a factor of 10 between the pristine condition and the 1980's, and half as much for the reference situation as for the 1980's (Fig. 7a). Whereas phosphorus flux was also twofold less for the reference situation than for the 1980's, the level did not show much further decrease for the pristine level. Pristine silica flux was slightly higher than the reference one.
The negative $\mathrm{N}$ - and P-ICEP indicated no risk for eutrophication in the pristine scenario, while both $\mathrm{N}$ - and P-ICEP were positive in the 1980 's (i.e., excess N and P compared to silica), corroborating the eutrophication observed at that time, before tertiary treatment implementation (Fig. 7b).

\subsubsection{The impact of agricultural changes}

We tested two contrasting agricultural scenarios (Garnier et al., 2018; Desmit et al., 2018). As a first step, we considered the same current conventional rotations, with full application of the current regulations (balanced fertilization following the agronomical recommendation with respect to current yield objectives and catch crop introduction before spring crops, Justes et al., 2012), called good agricultural practices (GAP). The second scenario assumes a radical change in the present agro-food system, in line with the current rapid increase in the demand for organic food and debates around the proportion of animal products in the human diet (Solagro, 2014). We therefore elaborated this scenario by generalizing organic farming in the Loire Basin, based on (i) long and diversified rotations without recourse to mineral fertilizers, (ii) reconnection of livestock and crop farming, using the local forage following the specification for organic cattle breeding and (iii) a human diet based on half the current animal protein ration substituted by grain legumes (the "Autonomous-Organic-Demitarian scenario" Auto-Org-Dem) (Billen et al., 2014; Garnier et al., 2016). Both agricultural scenarios include full compliance with the UWWTD prescriptions.

As expected, no visible changes were observed for phosphorus and silica for the two agricultural scenarios compared to the reference (Fig. 7). Nitrogen-specific fluxes (per $\mathrm{km}^{2}$ ) decreased by $15 \%$ and $30 \%$ for the GAP and Auto-Org-Dem, respectively. The effect was even higher 

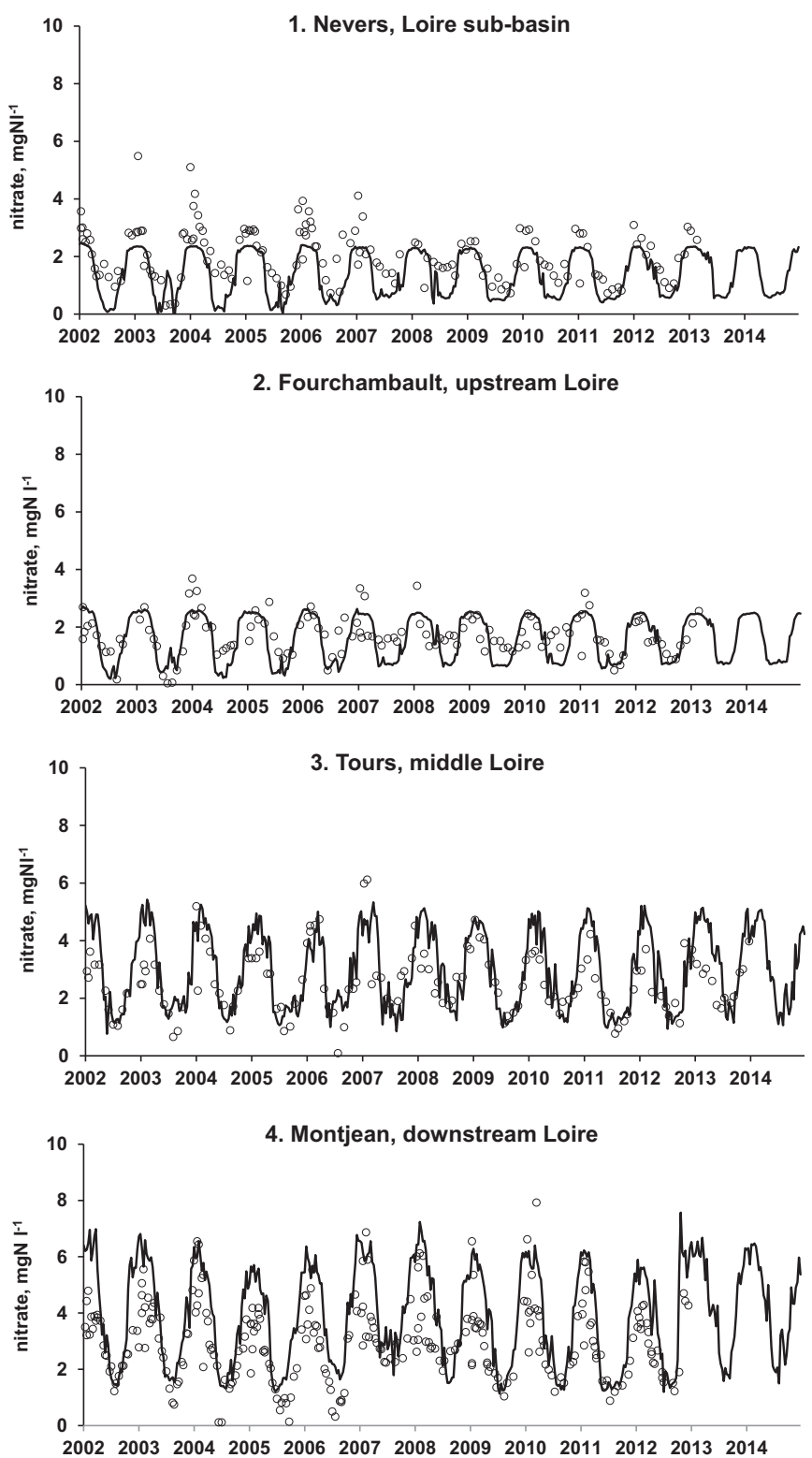

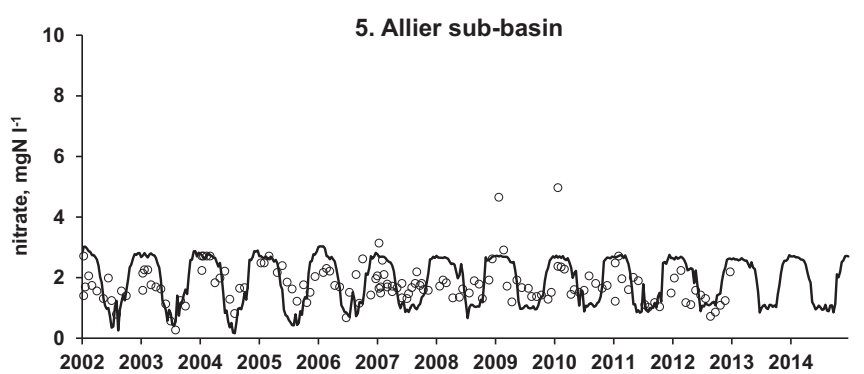

6. Vienne sub-basin

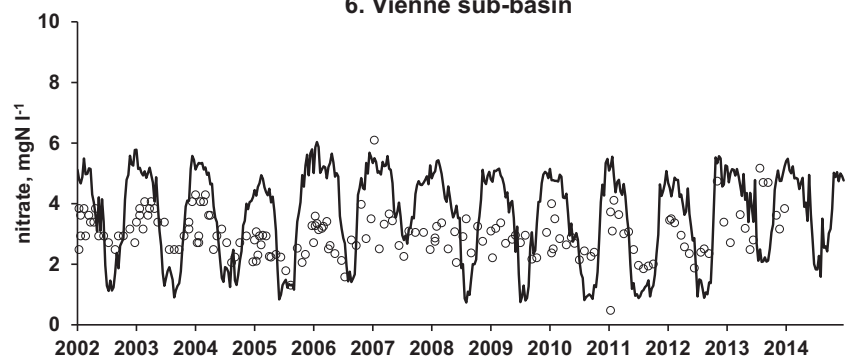

7. Mayenne sub-basin

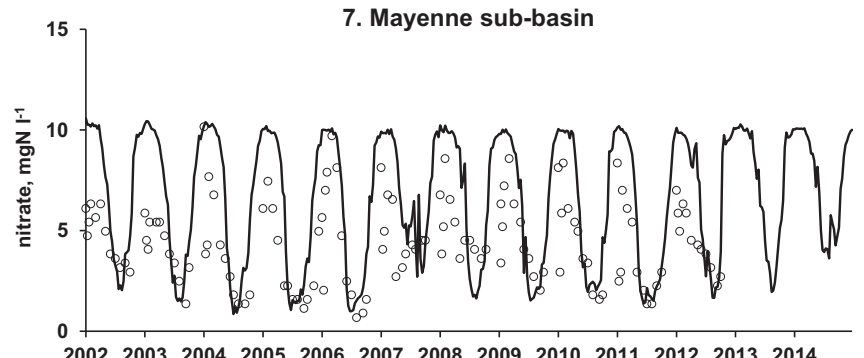

8. Loir sub-basin

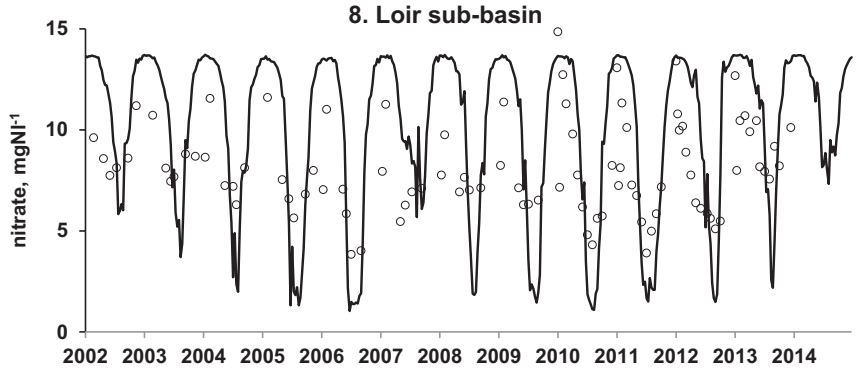

Fig. 6. Simulations by the Grafs-Seneque-Riverstrahler model of the seasonal variations of nitrate for various locations within the Loire River network. Comparison with observations.

Table 4

Variation in simulated annual average discharge and nutrient flux (nitrogen, N, phosphorus, P; silica, Si) for the period studied (2002-2014) at the outlet of the Loire River network (Montjean-sur-Loire, namely Montjean). The indicator of coastal eutrophication potential (ICEP) is shown for $\mathrm{P}$ and $\mathrm{N}$.

\begin{tabular}{lllllll}
\hline Years & $\begin{array}{l}\mathrm{Q} \\
\mathrm{m}^{3} \mathrm{~s}^{-1}\end{array}$ & $\begin{array}{l}\mathrm{FlxN} \\
\mathrm{ktN} \mathrm{yr}^{-1}\end{array}$ & $\begin{array}{l}\mathrm{FlxP} \\
\mathrm{ktP} \mathrm{yr}^{-1}\end{array}$ & $\begin{array}{l}\text { FlxSi } \\
\mathrm{ktSi} \mathrm{yr}^{-1}\end{array}$ & $\begin{array}{l}\text { N-ICEP } \\
\mathrm{kgC} \mathrm{km}^{-2} \mathrm{~d}^{-1}\end{array}$ & $\begin{array}{l}\text { P-ICEP } \\
\mathrm{kgC} \mathrm{km}^{-2} \mathrm{~d}^{-1}\end{array}$ \\
\hline 2002 & 798 & 1425 & 44 & 1238 & 14.7 & -2.8 \\
2003 & 857 & 1551 & 47 & 1370 & 15.8 & -3.3 \\
2004 & 895 & 1508 & 48 & 1398 & 15.0 & -3.4 \\
2005 & 600 & 914 & 33 & 926 & 8.6 & -2.0 \\
2006 & 735 & 1271 & 34 & 1143 & 12.8 & -3.3 \\
2007 & 906 & 1548 & 34 & 1456 & 15.2 & -5.3 \\
2008 & 1046 & 1745 & 38 & 1757 & 16.4 & -6.7 \\
2009 & 620 & 1010 & 23 & 979 & 9.8 & -3.5 \\
2010 & 842 & 1333 & 31 & 1375 & 12.4 & -5.2 \\
2011 & 457 & 725 & 18 & 701 & 7.0 & -2.4 \\
2012 & 790 & 1310 & 30 & 1289 & 12.5 & -4.7 \\
2013 & 1219 & 2131 & 44 & 2068 & 20.6 & -8.1
\end{tabular}

for N-ICEP, which decreased by $25 \%$ and $55 \%$ for the GAP and Auto-OrgDem, respectively (Fig. 7).

The results in N, P and Si concentrations where mapped for the period showing improved water quality (2008-2014) and for the whole drainage network of the Loire River, to compare the reference situation with the two scenarios, 1980's and Auto-Org-Dem (Fig. 8). These maps clearly show a degradation of water quality from upstream to downstream, especially regarding nitrate concentrations for the reference situation. Poor water quality was evident in the 1980's in terms of $\mathrm{N}$ and $\mathrm{P}$, and even for silica, which was quite depleted, all resulting in strongly eutrophic conditions, expressed as chlorophyll $a$ concentrations.

\subsubsection{Effect of climate change on water quality of the Loire River}

The pessimistic scenario in terms of discharge perturbations ARPEGE-SRES A2 using the hydrological model EROS (BRGM, Thiéry, 2018) showed a striking reduction of the discharge from $830 \mathrm{~m}^{3} \mathrm{~s}^{-1}$ on average for the values observed in 2002-2014 (765 $\mathrm{m}^{3} \mathrm{~s}^{-1}$ on average for the same period when calculated from SAFRAN mesoscale 
a.
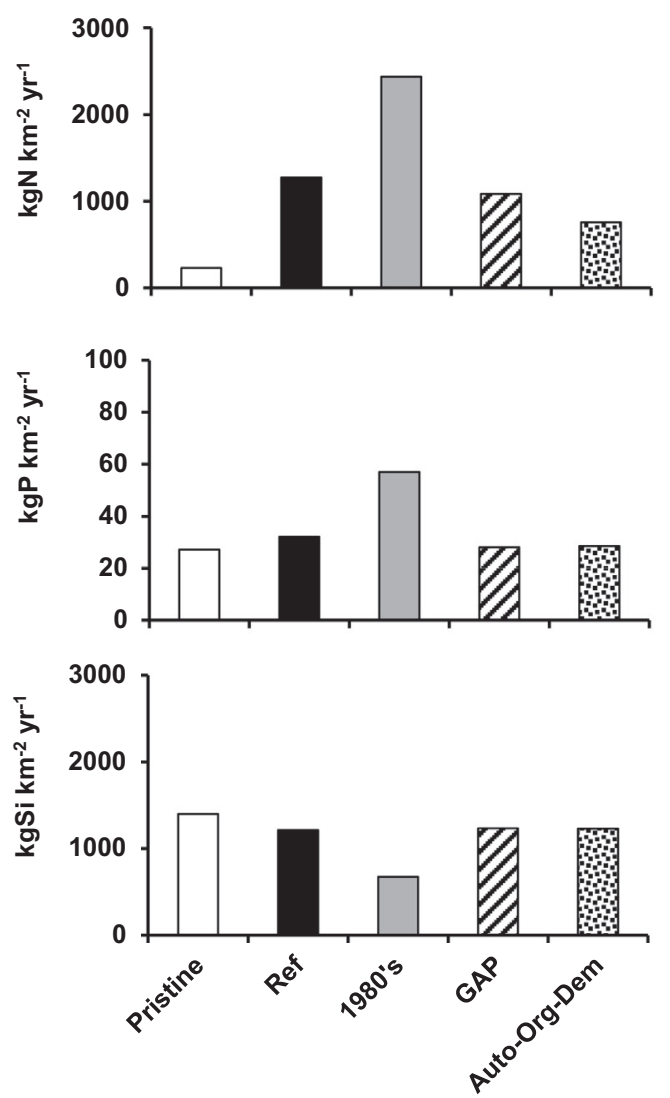

b.
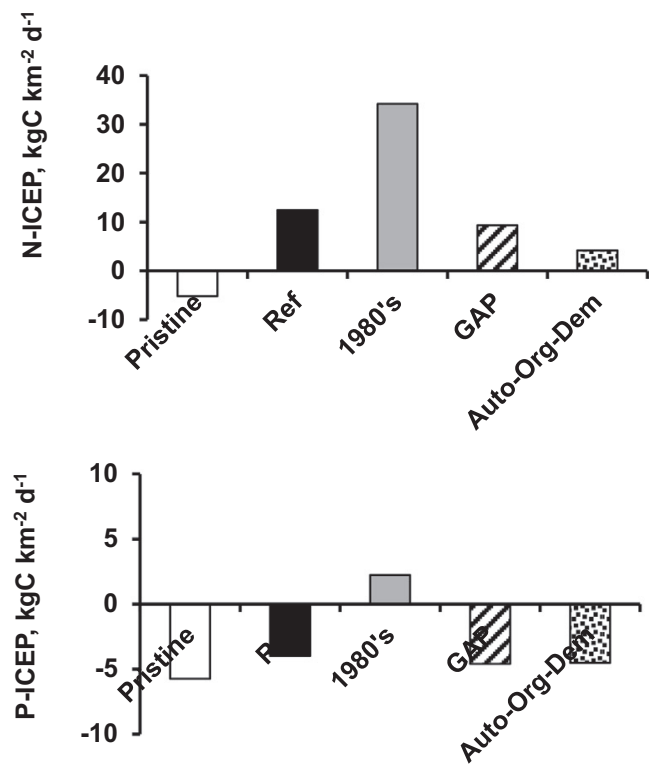

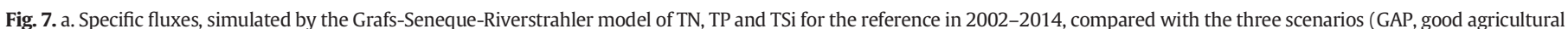

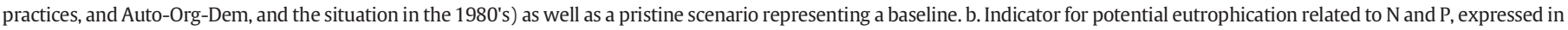
specific carbon fluxes for comparison. Results at the Montjean-sur-Loire station (Montjean), the outlet of the Loire River (see Fig. 1).

analysis system) to $320 \mathrm{~m}^{3} \mathrm{~s}^{-1}$ for the $2090-2100$ climate projection (Fig. 9).

Riverstrahler was run with the resulting EROS hydrology for two periods (2002-2014 and 2090-2100), for the reference inputs as well as for the 1980's scenarios with low wastewater treatment (1980's) and Auto-Org-Dem with a radical change in the agro-food system. No demographic change was taken into account between the two periods.

Nutrient fluxes delivered at the outlet of the Loire Basin (Fig. 10) with the hydrology resulting from climate change showed a notable decrease due to decreasing discharges. As a result, N-ICEP was reduced to one third of the reference situation, while remaining positive. P-ICEP would not be as negative, since urban effluents are somewhat concentrated with lower discharge. The same trends were observed for the 1980 's and Auto-Org-Dem scenarios, with the worst situation without efficient wastewater treatment, and the best one with alternative agriculture.

Focusing on the summer 2008-2014 period, eutrophication in the drainage network which can be still problematic for the reference situation, less for the Auto-Org-Dem scenario, but worse for the 1980's one, is further accentuated under climate change hydrology (Fig. 11a and b). Relaxing efforts in the treatment of wastewater (i.e., coming back to the 1980 situation) would considerably worsen eutrophication at a level already experienced, for the current hydrology and even more under climate change. Whereas a radical change in agriculture (Auto-Org-Dem scenario) appears as the only way to reduce nitrate contamination and considerably weaken the problem of eutrophication in the current hydrology, the effect on eutrophication of such a deep change would be undermined under climate change (Fig. 11). At total, despite eutrophication would be reduced at the marine coastal water under climate change hydrology, eutrophication within the river drainage network would increase notably, especially with poor treatment in WWTPs.

\section{Discussion}

The modeling approach implemented at the whole basin scale differs from the several other studies already published on the Loire River, focusing mostly on the middle Loire River (Minaudo et al., 2018; Descy et al., 2011), from the Allier to the Maine rivers, close to the Montjean-sur-Loire outlet station. Taking into account upstream basins (upper Loire and Allier), as well as all tributaries, made it possible to synthesize most of the data available over this large territory covering $20 \%$ of France, to quantify nutrient fluxes and eutrophication. Moreover, we elaborated a wide range of scenarios, exploring extreme changes in human management of the watershed related to wastewater treatment and agricultural activities, as well as the possible effect of climate change on the hydrological regime of the river system. These scenarios can guide future management measures (see Sabater et al., 2008).

\subsection{The models and their evaluation}

The Riverstrahler model has been applied to a large range of rivers size $\left(100 \mathrm{~km}^{2}\right.$ to $\left.800,000 \mathrm{~km}^{2}\right)$ under temperate regime (Garnier et al., 2002, 2016), in a gradient from temperate to Mediterranean climate (Desmit et al., 2018), and for subtropical (Le et al., 2014) and cold rivers (Sferratore et al., 2008) analyzing nutrients fluxes and eutrophication at the scale of whole watershed, with the same sets of equations and parameters, proving therefore its robustness. No calibration other than the range of the determination of the parameters is 

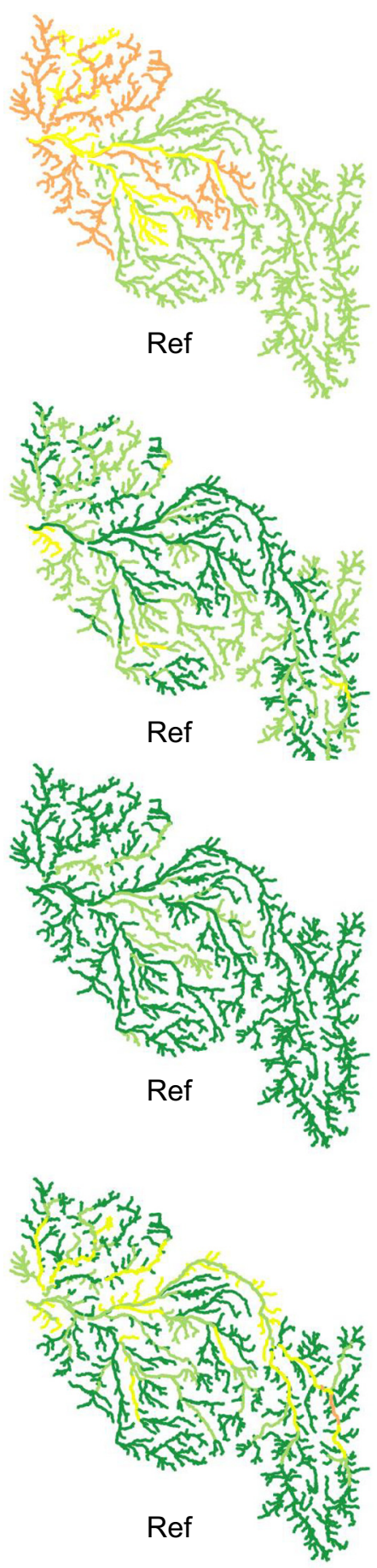
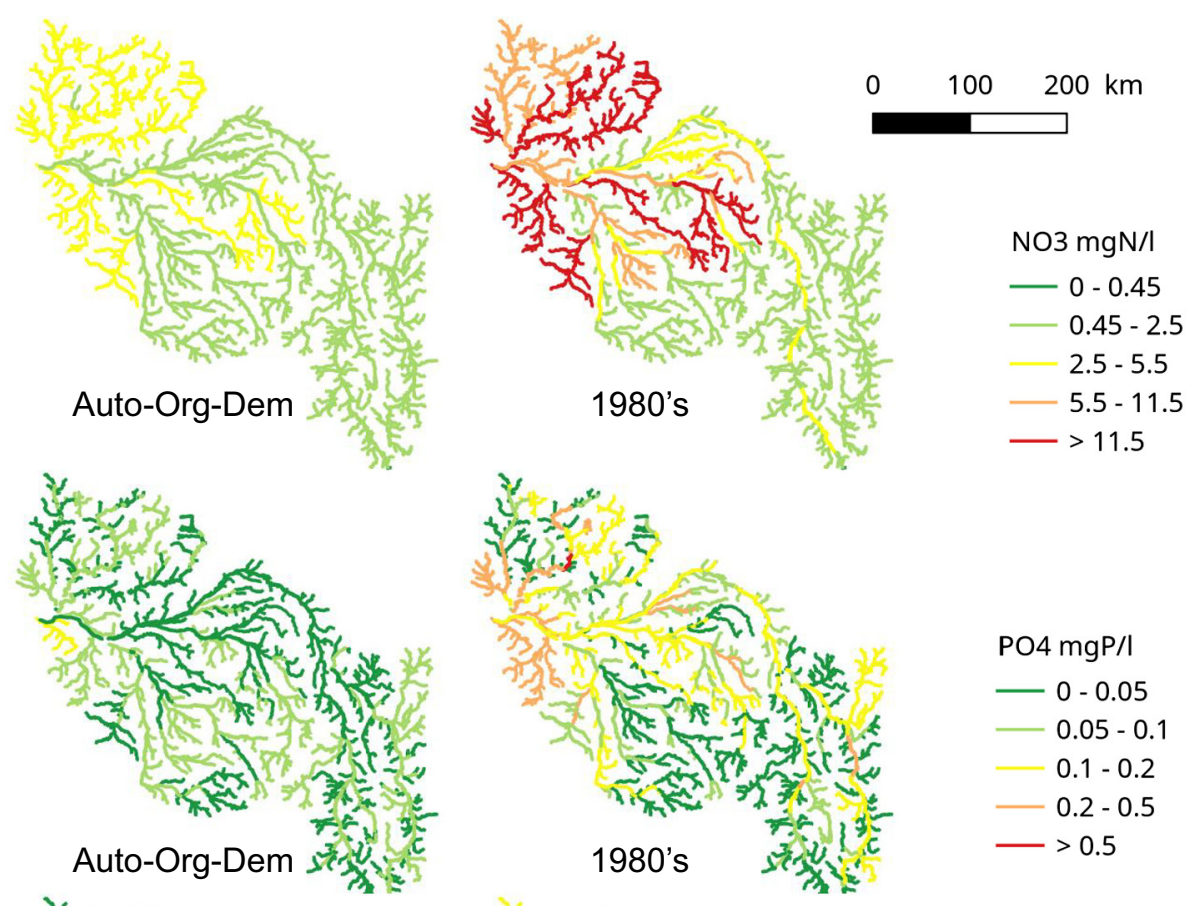

NO3 mgN/l

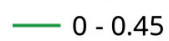

$0.45-2.5$

$2.5-5.5$

$-5.5-11.5$

$\longrightarrow>11.5$
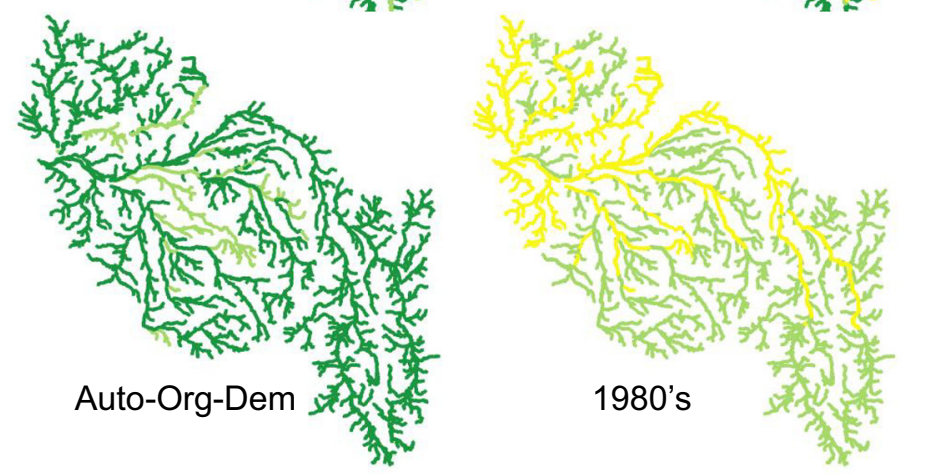

SiO3 mgSi/l

- 0 - 1

$-1-2$

$-2-3$

$3-4$
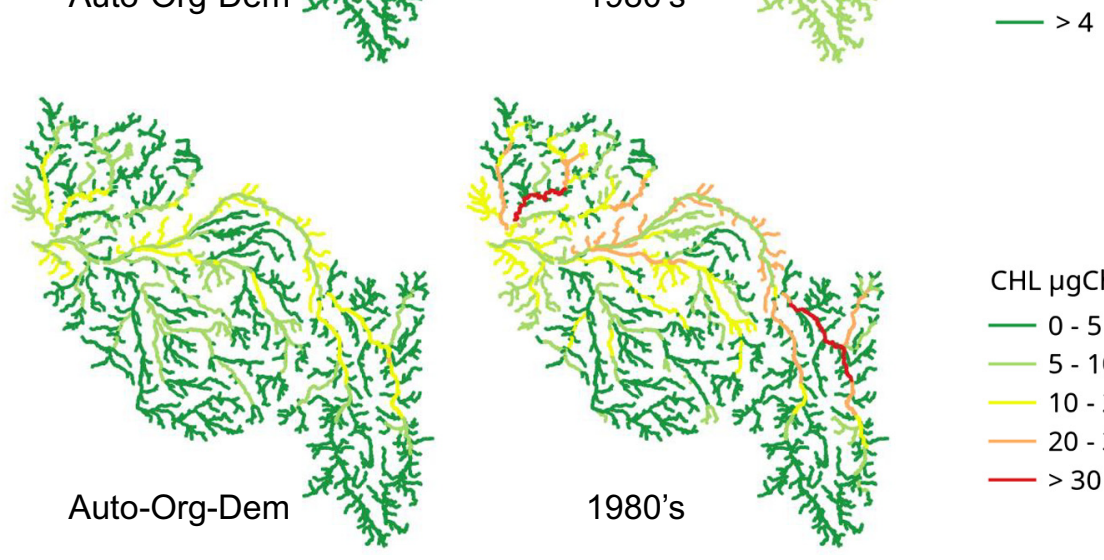

CHL $\mu g C h l a / l$

$0-5$

$5-10$

- $10-20$

$20-30$

$->30$

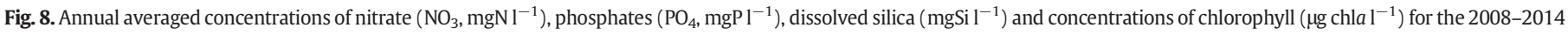
period, distributed within the drainage network of the Loire River for two scenarios (Auto-Org-Dem and 1980's) compared to the reference.

necessary. It has also been used for exploration of a large variety of scenarios regarding domestic or agricultural pollution (Thieu et al., 2010; Passy et al., 2016). Several river models exist in literature, based on statistical approaches (GREEN, Grizzetti et al., 2012) or are more hybrid, both process- and statistics-based (SPARROW, Alexander et al., 2002; MONERIS, Venohr et al., 2011). These models were used for estimating the global distribution of nutrients export from large river. Fully based-process models such as SWAT (Arnold et al., 1998; Malagó et al., 2017), RiNUX (Loos et al., 2009) require calibration procedures, whereas Riverstrahler (Billen et al., 1994; Garnier et al., 2002; Garnier et al., 2018), PEGASE (Descy et al., 2011) and QUAL-NET (Minaudo et al., 2018) are more generic. When metrics are calculated for evaluating these models, NRMSE, slopes or biases are chosen. However, most of the model evaluation relies only on a single station at the outlet of the watershed (Wellen et al., 2015). A better performance is necessarily expected for a model describing a stretch of river (Minaudo et al., 2018, specifically for Loire River) than for other at a whole watershed scale (e.g., Malagó et al., 2017, for the Danube) as it is the case in our study.

\subsection{Wastewater treatment and eutrophication reduction}

Exactly as was the case for many other European rivers, the Loire River was severely eutrophied in the 1980's (Moatar and Meybeck, 

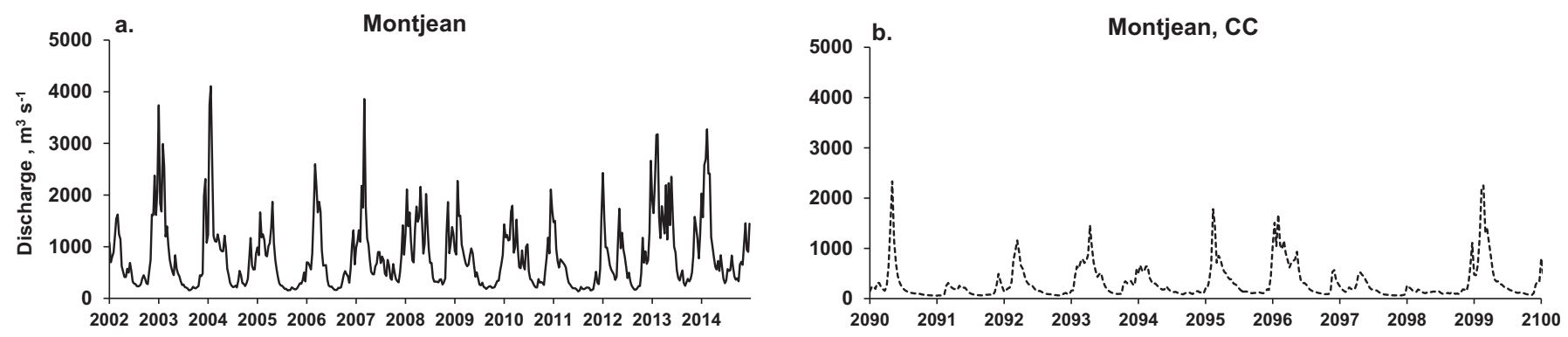

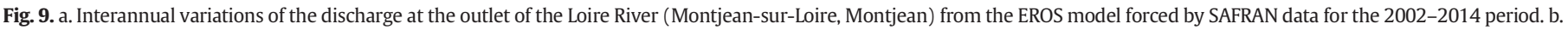
Comparison with the EROS values obtained for the ARPEGE SRES A2 scenario of climate change (CC) for the 2090-2100 period.

2005). The successful implementation of European directives, namely UWWTD (Urban wastewater treatment Directive, 91/271/CEE UWWD, 1991 ) and the WFD (Water Framework Directive, 200/60/CE, 2000), led to a substantial reduction of algal development and hence eutrophication in the main stems of many European rivers. In the Loire River, whereas algal blooms recurrently exceeded $120 \mu \mathrm{g}$ chl $a$ in the 1980's (Crouzet, 1983; Floury et al., 2012; Minaudo et al., 2015), values at the Montjean-sur-Loire station peaked at $80 \mu \mathrm{g}$ chl $a$ in the early 2000s, with the maximum values reduced to $50 \mu \mathrm{g} c h l a$ in the last years of the period studied (2008-2014). This change was clearly linked to the reduction in phosphate loading, with concentrations reaching

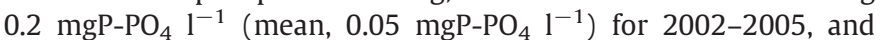

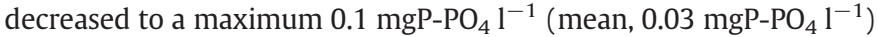
for 2009-2012. Exactly as observed on the Seine River, the response in eutrophication was not linear with phosphate elimination in wastewaters (Passy et al., 2013; Aissa Grouz et al., 2016), phytoplankton continuing to form blooms as long as phosphorus was not limiting,

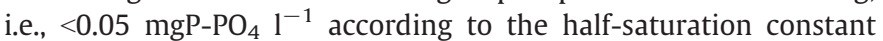
(Garnier et al., 1995). Despite the role of Corbicula invasion that has been cited to explain a phytoplankton biomass decrease in the Loire River following Brancotte and Vincent (2002), no information is currently available regarding the population density of this benthic filter feeder mollusk and its dynamics (see Floury et al., 2012). The Riverstrahler model, which takes into account a realistic benthic filtration since Garnier et al. (2000), clearly showed here that reducing phosphate loading plays a major role on phytoplankton development once its concentration has reached limiting values. However, the system can be still exposed to eutrophication when wastewater is
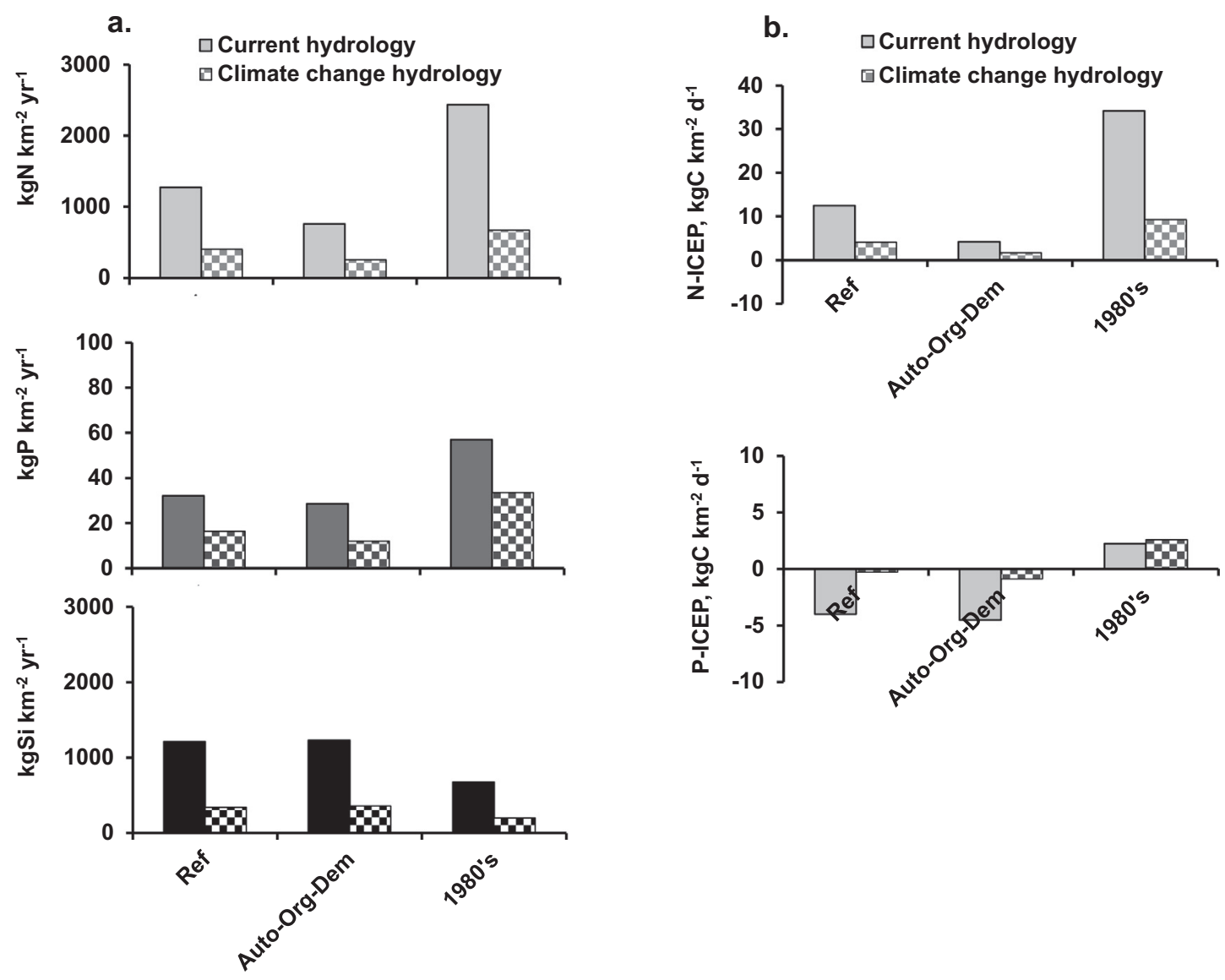

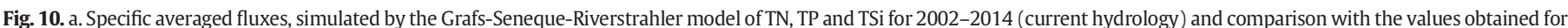

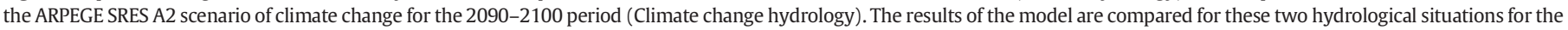

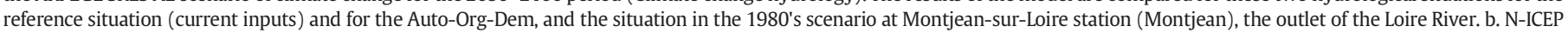
and P-ICEP are also shown for current and climate change hydrology. 


\section{a. Current hydrology}

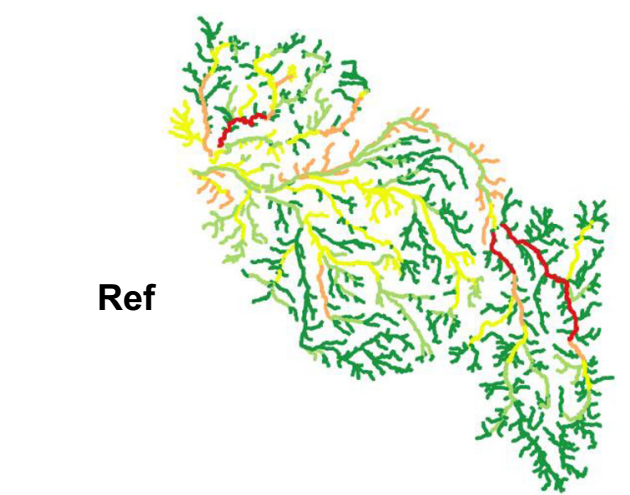

b. Climate change hydrology

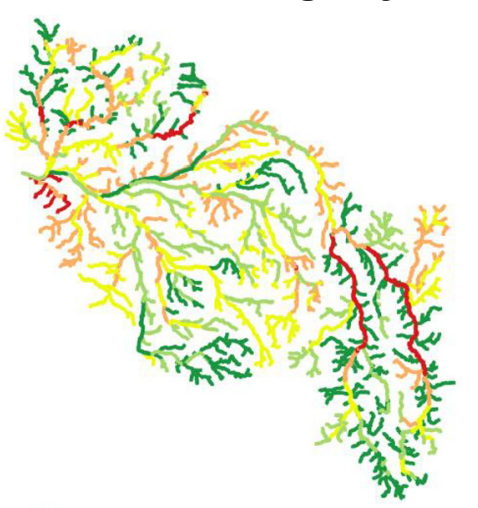

$\widehat{A}_{N}$
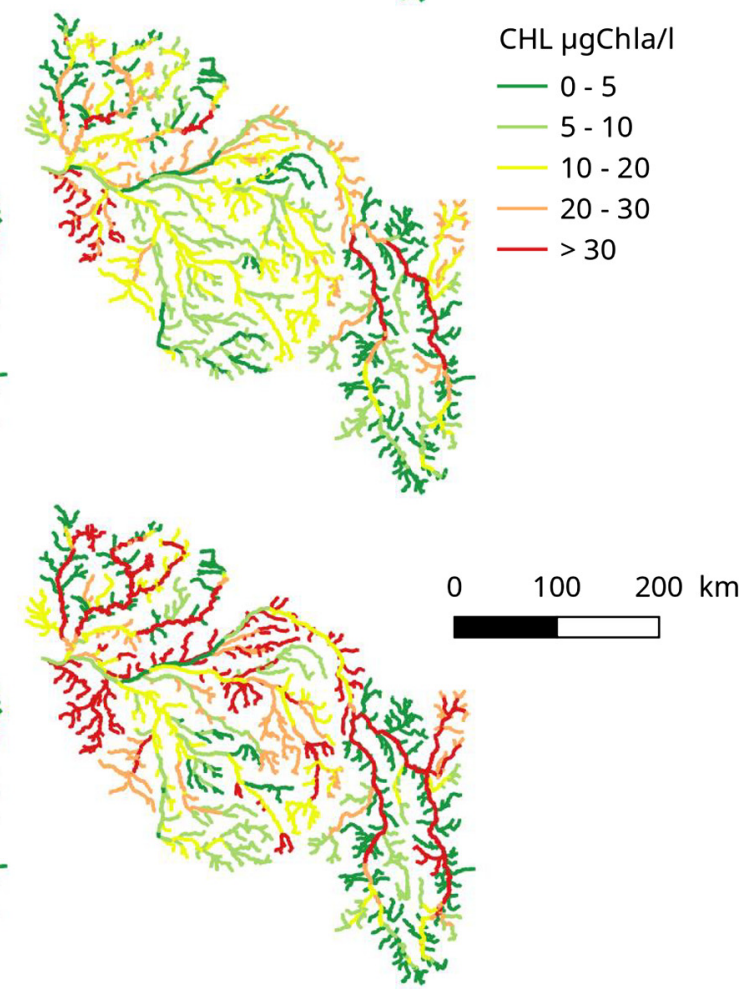

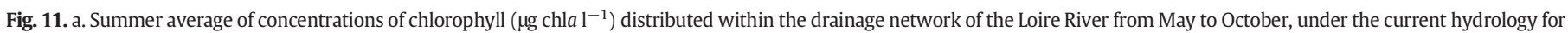

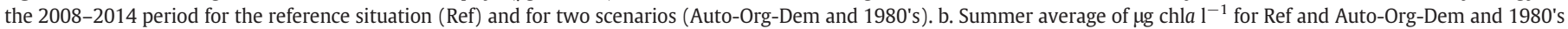
scenarios, under climate change hydrology.

"concentrated" in low water fluxes. This situation was observed in 2011 in the Seine River, although phytoplankton development was already limited from 2008 onward (Aissa Grouz et al., 2016).

Major remarkable changes already reported regarding improvement of eutrophication concerned a phosphorus decrease for most large rivers of the Atlantic and North Mediterranean coasts (Romero et al., 2013; Abbott et al., 2018), even at the whole EU scale where nitrogen did not change much, so that the N:P ratio increased (Grizzetti et al., 2012).

\subsection{Nitrate contamination due to long-lasting diffuse pollution}

Nitrogen concentrations in the Loire River remained stable for the period studied here, as has been the case since the 1980's (Minaudo et al., 2015). This showed that the wastewater treatment efforts did not affect nitrogen as much as phosphorus, simply because a high proportion of nitrate comes from diffuse agriculture sources. The EU Nitrate Directive 91/676/CEE (European Council, 1991), imposing regulations on agricultural practices, has not yet been efficient in decreasing surface and groundwater contamination due to agricultural N pollution. Yet, Lassaletta et al. (2014) showed a reduction in applied nitrogen fertilizers in the 1990's at the country scale from 180 to $200 \mathrm{kgN} \mathrm{ha}^{-1} \mathrm{yr}^{-1}$ to $150-160 \mathrm{kgN} \mathrm{ha}^{-1} \mathrm{yr}^{-1}$ in the 2010 's, with more efficient nitrogen use. The same trends have been observed for the Loire Basin (Poisvert et al., 2017; Le Noë et al., 2017). The delayed response of nitrogen may be due to the residence time of the aquifers on the order of 30-50 years (Flipo, 2005) in the Central Loire basin, in much the same way as the Seine basin, and to the migration time of excess fertilizers from soil to aquifers. Nitrate accumulation in the aquifers must be considered as a legacy related to an excess of fertilization for agriculture intensification from the 1950's. Consequently, any effort made by farmers in fertilizer applications and practices since the 1990's in this part of the basin would be noticeable in the next decade at the earliest.

On the other hand, nitrate elimination at the riparian interface between ground- and surface water can reach $15 \%$ of the diffuse sources, and a further $15 \%$ can be eliminated based on in-stream benthic denitrification, as taken into account in the model (Billen et al., 2018). Nitrate concentrations were reliably reproduced by the model both in terms of 
the interannual high winter level and seasonal variations with their substantial summer reduction. Interestingly, when not taking into account riparian denitrification, amplitude of nitrate variations were not captured (not shown, but see Billen et al., 2018), showing that this riparian process, rather than algal uptake, is responsible for the low nitrate levels in summer, as questioned by Minaudo et al. (2015). The maximum nitrate concentration reduction due to uptake by an algal bloom of $100 \mu \mathrm{g} \mathrm{Chla}{ }^{-1}$, taking into account a C:N = 106:16 (molar Redfield Ratio) and a C:Chla ratio of 30 , would be about $0.5 \mathrm{mgN}^{-1}$, much lower than the 5-6 mgN-NO $\mathrm{l}^{-1}$ observed.

Riparian and benthic in-stream denitrification, however, is greatly reduced in intensity during winter high-water periods due to low temperatures, which strongly reduced their effect on the annual budget of nitrogen delivery to coastal zones.

\subsection{Combatting eutrophication and nitrate contamination}

Eutrophication in the Loire River has been efficiently combatted in the last two decades through phosphate reduction, first when phosphates were banished from washing powder in the late 1980's in France and then when phosphate treatment of wastewater was improved in the 2000's. Further P loading reduction is expected in the near future due to the regulation of dishwashing detergents (Official Journal of the European Union Regulation, 2012), which still account for $20 \%$ of total domestic waste. Besides $P$ point sources, diffuse inputs from erosion must be avoided by adapted agricultural practices and wetlands/riparian zones restoration (Dorioz and Trevisan, 2013). Also, $P$ dynamics and release of dissolved $P$ downslope in riparian zones should be taken into account (Gu et al., 2017). However, a major issue would be to avoid any disengagement from local communities in the treatment of domestic or industrial wastewaters. The scenario of lower sanitation showed a return to the conditions of the 1980's. This situation could occur with population settlement and/or development of tourism activity in this region of the Loire Valley, considered the most attractive of northern France (low population density, pleasant climate) with the Middle Loire now registered as a United Nations Environmental, Scientific, and Cultural Organization (UNESCO) World Heritage Site (Breting-Garcia, 2014).

Reducing nitrate contamination is a major challenge, especially in the middle part of the basin where its fertile land sustains intensive cereal cultivation. Good agricultural practices (GAP), as recommended by Comifer (Comité Français d'Étude et de Développement de la Fertilisation Raisonnée, i.e., French Committee for the Study and the Development of Rational Fertilization Practices, created in the dark years of the 1980 's, as far as environment is concerned), have not been able to considerably reduce nitrate pollution (13\% in average for all the stations compared to the Reference). Changing the structure of the agro-food system appears to be the only way to further decrease nitrate flux (34\%), with a reduced risk of eutrophication at the coastal zone, as shown by the N-ICEP value, closer to zero, i.e., tending to N:Si equilibrium regarding the marine algae requirement. The radical change explored with the Auto-Org-Dem scenario, which assumes organic agriculture, with part of forage dedicated to local livestock within the limit of cattle loading specified by organic agriculture regulations and a demitarian human diet, would respond to the local food demand and would allow exporting cash crops and animal products to more populated regions such as the Ile-de-France region.

Despite our assumption of a reduction of animal proteins in the diet converge with the view reported by Clark and Tilman (2017) for a sustainable agriculture, our study also showed, differently from these authors, that generalizing organic farming would reduce eutrophication (based on our indicator taking into account N:P:Si ratios rather than only P). In addition to eutrophication, other environmental benefits of our scenario would be less $\mathrm{NO}_{3}$ leaching to groundwater resources, a reconnection of crop and livestock farming, and the banishment of pesticides, the adverse effects of which are well demonstrated for public health (Cimino et al., 2017) and biodiversity (Camargo et al., 2005; James et al., 2005). In addition, we experimentally showed, for the north of France, a decrease in $\mathrm{N}_{2} \mathrm{O}$ emissions under organic farming (Benoit et al., 2015). In the line of Clark and Tilman (2017) however, our scenario needs to be further explored for other climatic and soils conditions, including low-income countries rather that the rich ones of the north of France, studied here.

\subsection{Hydrological impact on ecological functioning of the river under climate change}

We used here the SRES A2 scenario (Special Report on Emissions Scenarios) from the previous IPCC reports (2001 and 2007), although a new approach was adopted in the 5th IPPC report (2014) with the definition of four Representative Concentration Pathways (RCP). Although RCP scenarios cover a longer period than the four A1, A2, B1 and B2 families (up to 2300 vs. 2100 respectively) these scenarios are comparable, with RCP8.5 close to the A2 scenario, being the most pessimistic in terms of $\mathrm{CO}_{2}$ emissions (Ouzeau et al., 2014).

The hydrological model EROS (BRGM, Thiéry, 2018) was forced with the results of the ARPEGE GCM (General Circulation Model, Déqué et al., 1994) run for the A2 scenario and downscaled with a statistical method (Boé et al., 2009).

This scenario considered the ecological impact of climate change though hydrological conditions only. The population variable was not modified and temperature values were kept similar to reference values.

The available population estimates increase for the Loire Basin at the Horizon 2050 (INSEE, https://www.insee.fr/fr/statistiques/2867738) is about $0.17 \% \mathrm{yr}^{-1}$, which would mean about 5 inhab. $\mathrm{km}^{-2}$ more than the 63.6 inhab. $\mathrm{km}^{-2}$ for 2015. Considering sanitation efficient enough according to complementary directives or recycling alternative management of human excretion (Esculier, 2018; Esculier et al., 2018), this population increase might not significantly modify nutrient inputs to the river.

Regarding temperature, mean water values have indeed already increased by 2.4 to $3{ }^{\circ} \mathrm{C}$ in spring and summer since 1975 (Moatar and Gailhard, 2006; Boé et al., 2009; Bustillo et al., 2014). Since temperature is an important factor controlling biological processes, it deserves more attention in this modeling approach. However, a myriad of other factors influence phytoplankton development such as nutrients, light, hydrology and top-down control by animals. Hydrology has been shown to be a major factor in river water, with phytoplankton biomass increasing when the growth rate is superior to the dilution rate by the discharge (Garnier et al., 1995). In addition, heavy rains during a bloom can lead to its collapse (Garnier et al., 1991). Therefore, taking hydrology as the main factor of change appears relevant in the first step. Also, this stepwise approach can disentangle the respective contribution of a change in hydrological regimes, independently from other climate-impacted variables. Whatever the scenarios tested, present conditions, radical change in agriculture or a low level of wastewater treatment similar to that in the 1980's situation, a decrease in discharge logically decreases nutrient fluxes. Because changes in nutrient fluxes are not proportional to the discharge, with point sources behaving differently from diffuse sources, imbalance in nutrients would be modified in such a way that the risk of coastal eutrophication would be close to zero, surprisingly, as shown by the N- and P-ICEP. However, climate change would have an adverse effect within the drainage network by worsening eutrophication in spite of the major improvements already obtained through implementation of enhanced wastewater treatment. Lower discharges, and hence higher residence times of the water, would modify the distribution of algal development in the network, promoting upstream blooms. Such an algal development would be made possible by less dilution of nutrients from point sources, at low waters.

Interestingly, the hydrological impact under climate change on the ecological functioning of the Loire River would differ from that obtained for the Seine, where $\mathrm{N}$ and $\mathrm{P}$ fluxes would increase as well as ICEP 
values, with an overall increase by a few percent of the annual discharge (Raimonet et al., 2018). Differences between the Seine and the Loire rivers are not surprising considering their respective average discharge that would converge to a same level by the end of the 21st century, with a Loire Basin's population kept identical to the present one, i.e., half that of the Seine (with no change either).

\section{Conclusions}

In contrast to numerous previous studies focusing on the middle Loire Valley, the Grafs-Seneque-Riverstrahler modeling approach summarizes data at the scale of the entire watershed to analyze nutrient contamination and eutrophication risk. Thanks essentially to improvement of wastewater treatment following the implementation of the UWWD and EU-WFD mainly focusing on decreasing phosphorus loading, eutrophication of the Loire River has been considerably reduced. The period studied was here limited to 13 years, but once data are available on constraints and validation, the approach can be applied to longer periods in the past, as done for the Seine River (Passy et al., 2013). Instead, the modeling approach has been used here to explore scenarios showing that any relaxation in wastewater treatment would lead to returning to the situation that existed in the 1980 's, while only a deep change in the agro-food system would reduce the risk of eutrophication at the coast. Under climate change, despite a reduction of coastal eutrophication, river eutrophication would considerably increase, which highlights the need for both reducing nitrogen fluxes with deep agricultural changes and further treating phosphorus point sources.

As developed by Jarvie et al. (2018), we showed here how both P and $\mathrm{N}$ inputs to surface waters must be taken into account to limit water degradation and eutrophication along the river aquatic continuum.

Supplementary data to this article can be found online at https://doi. org/10.1016/j.scitotenv.2018.05.045.

\section{Acknowledgements}

This ICC-HYDROQUAL Projet was funded via the Plan Loire Grandeur Nature (2007-2015), (Etablissement Public Loire). Agence de l'Eau Loire-Bretagne is greatly acknowledged for providing information and data on the Loire River. Thanks are due to the PIREN-Seine program, which supported the development of the Grafs-Seneque-Riverstrahler on the Seine River. We acknowledge four anonymous reviewers for their constructive comments and suggestions.

\section{References}

Abbott, B.W., Moatar, F., Gauthier, O., Fovet, O., Antoine, V., Ragueneau, O., 2018. Trends and seasonality of river nutrients in agricultural catchments: 18 years of weekly citizen science in France. Sci. Total Environ. 624, 845-858.

Aissa Grouz, N., Garnier, J., Billen, G., 2016. Long trend reduction of phosphorus wastewater loading in the Seine: determination of phosphorus speciation and sorption for modeling algal growth. Environ. Sci. Pollut. Res. https://doi.org/10.1007/s11356016-7555-7.

Alexander, R.B., Elliott, A.H., Shankar, U., McBride, G.B., 2002. Estimating the sources and transport of nutrients in the Waikato River basin, New Zealand. Water Resour. Res. $38,1268-1290$.

Anglade, J., 2015. Agriculture biologique, qualité de l'eau et gouvernance. Ph-D Univ. Paris 6 (UPMC), Ecole Doctorale "Géosciences et Ressources Naturelles" (286 pp.).

Anglade, J., Billen, G., Garnier, J., 2017. Reconquérir la qualité de l'eau en régions de grande culture: agriculture biologique et reconnexion avec l'élevage. Fourrages $n^{\circ} 231$. pp. 257-268.

Arnold, J.G., Allen, P.M., 1999. Automated methods for estimating baseflow and ground water recharge from streamflow records. J. Am. Water Resour. Assoc. 35, 411-424.

Arnold, J.G., Srinivasan, R., Muttiah, R.S., Williams, J.R., 1998. Large area hydrologic modeling and assessment: part I. Model development. J. Am. Water Res. Assoc. 34 (1), 73-89.

Benoit, M., Garnier, J., Billen, G., Tournebize, J., Gréhan, E., Mary, B., 2015. Nitrous oxide emissions and nitrate leaching in an organic and a conventional cropping system (Seine basin, France). Agric. Ecosyst. Environ. 213:131-141. https://doi.org/10.1016/ j.agee.2015.07.030.

Billen, G., Garnier, J., 1997. The Phison River Plume: coastal eutrophication in response to changes in land use and water management in the watershed. Aquat. Microb. Ecol. $13,3-17$.
Billen, G., Garnier, J., 2007. River basin nutrient delivery to the coastal sea: assessing its potential to sustain new production of non siliceous algae. Mar. Chem. 106, $148-160$.

Billen, G., Garnier, J., Hanset, P., 1994. Modelling phytoplankton development in whole drainage networks: the RIVERSTRAHLER model applied to the Seine river system. Hydrobiologia 289, 119-137.

Billen, G., Lasseletta, L., Garnier, J., 2014. A biogeochemical view of the global agro-food system: nitrogen flows associated with protein production, consumption and trade. Glob. Food Sec. 3:209-219. https://doi.org/10.1016/j.gfs.2014.08.003i.

Billen, G., Ramarson, A., Thieu, V., Théry, S., Silvestre, M., Pasquier, C., Hénault, C., Garnier J., 2018. Nitrate retention at the river-watershed interface: a new conceptual modeling approach. Biogeochemistry (in revision).

Boé, J., Terray, L., Martin, E., Habets, F., 2009. Projected changes in components of the hydrological cycle in French river basins during the 21st century. Water Resour. Res. 45 W08426. https://doi.org/10.1029/2008WR007437.

Bonnet, M.-P., Poulin, M., Devaux, J., 2000. Numerical modeling of thermal stratification in a lake reservoir. Methodology and case study. Aquat. Sci. 62:105-124. https://doi.org/ $10.1007 / \mathrm{s} 000270050001$.

Bossard, M., Feranec, J., Otahel, J., 2000. Corine Land Cover Technical Guide - Addendum 2000, Technical Report no 40. EEA, Copenhagen http://www.eea.eu.int.

Brancotte, V., Vincent, T., 2002. L'invasion du réseau hydrographique français par les mollusques Corbicula Spp. Modalité de colonisation et rôle prépondérant des canaux de navigation, B. Fr. Peche Piscic. 365-366 pp. 325-337 (in French).

Breting-Garcia, V.M., 2014. Loire River ecosystem. Salem Press Encyclopedia of Science. 2pp. 94981468;20180207; DataLoaderFramework.EpMarcCitation; 5.8.0.0. (Last reviewed: July 2016). Category: Inland Aquatic Biomes.

Bustillo, V., Moatar, F., Ducharne, A., Thiéry, D., Poirel, A., 2014. A multimodel comparison for assessing water temperatures under changing climate conditions via the equilibrium temperature concept: case study of the Middle Loire River, France. Hydrol. Process. 28, 1507-1524.

Camargo, J.A., Alonso, A., Salamanca, A., 2005. Nitrate toxicity to aquatic animals: a review with new data for freshwater invertebrates. Chemosphere 58, 1255-1267.

Cimino, A.M., Boyles, A.L., Thayer, K.A., Perry, M.J., 2017. Effects of neonicotinoid pesticide exposure on human health: a systematic review. Environ. Health Perspect. 125: 155-162. https://doi.org/10.1289/EHP515.

Clark, M., Tilman, D., 2017. Comparative analysis of environmental impacts of agricultural production systems, agricultural input efficiency, and food choice. Environ. Res. Lett. 12 (2017):064016. https://doi.org/10.1088/1748-9326/aa6cd5.

Conley, D.J., Kilham, S.S., Theriot, E.C., 1989. Differences in silica content between marine and freshwater diatoms. Limnol. Oceanogr. 34, 205-213.

Crouzet, Ph., 1983. L'eutrophisation de la Loire. Water Supply 1, 134-144.

Cugier, Ph., Billen, G., Guillaud, J.F., Garnier, J., Ménesguen, A., 2005. Modelling the eutrophication of the Seine Bight (France) under historical, present and future riverine nutrient loading. J. Hydrol. 304, 381-396.

Davidson, K., Gowen, R.J., Harrison, P.J., Fleming, L.E., Hoagland, P., Moschonas, G., 2014. Anthropogenic nutrients and harmful algae in coastal waters. J. Environ. Manag. 146, 206-216.

Déqué, M., Dreveton, C., Braun, A., Cariolle, D., 1994. The ARPEGE-IFS atmosphere model: a contribution to the French community climate modelling. Clim. Dyn. 10, 249-266.

Descy, J.P., Leitao, M., Everbecq, E., Smitz, J.S., Deliège, J.F., 2011. Phytoplankton of the River Loire, France: a biodiversity and modelling study. J. Plankton Res. 34, 120-135.

Desmit, X., Thieu, V., Dulière, V., Ménesguen, A., Campuzano, F., Lassaletta, L., Sobrinho J.L., Silvestre, M., Garnier, J., Neves, R., Billen, G., Lacroix, G., 2018. Reducing marine eutrophication may require a paradigmatic change. Sci. Total Environ. 635:1444-1466. https://doi.org/10.1016/j.scitotenv.2018.04.181.

Direction Générale de la Santé, 2012. Abandons de captages utilisés pour la production d'eau destinée à la consommation humaine. Bilan Février 2012, secrétariat d'Etat chargé de la santé. 22 pp.

Dorioz, J.-M., Trevisan, D., 2013. Le transfert diffus du phosphore dans les bassins agricoles : ordres de grandeur, mécanismes, maîtrise. Ingénieries (Special issue: 27-47).

Ducharne, A., Baubion, C., Beaudoin, N., Benoît, M., Billen, G., Brisson, N., Garnier, J., ... Mary, B., 2007. Long term prospective of the Seine River system: confronting climatic and direct anthropogenic changes. Sci. Total Environ. 375 (1-3), 292-311.

Dupas, R., Curie, F., Gascuel-Odoux, C., Moatar, F., Delmas, M., Parnaudeau, V., Durand, P., 2013. Assessing $\mathrm{N}$ emissions in surface water at the national level: comparison of country-wide vs. regionalized models. Sci. Total Environ. 443, 152-162.

EEA, European Environment Agency, 2007. CLC2006 Technical Guidelines. Technical Report no. 17/2007. European Environment Agency, Luxembourg.

Esculier, F., 2018. Le système alimentation/excrétion des territoires urbains: régimes et transition socio-écologiques. Thèse de l'Univ. Paris Est. Ecole Doctorale Sciences, Ingéniérie et Environnement. 478pp + annexes.

Esculier, F., Le Noé, J., Barles, S., Billen, G., Créno, B., Garnier, J., Lesavre, J., Petit, L., Tabuchi, J.-P., 2018. The biogeochemical imprint of human metabolism in Paris megacity: a regionalized analysis of a water-agro-food system. J. Hydrol. https://doi.org/10.1016/j. jhydrol.2018.02.043.

European Council, 1991. Official Journal of the European Communities (31-12-91). No L 375 / 1. EU Nitrate Directive 91/676/CEE. 8 pp. http://eur-lex.europa.eu/ legal-content/EN/TXT/PDF/?uri=CELEX:31991L0676\&from=EN (last accessed, 3 May 2018).

Flipo, N., 2005. Modélisation intégrée des transferts d'azote dans les aquifères et les rivières. Applications au bassin du Grand Morin. Ph-D Ecole Nationale Supérieure des Mines de Paris, 193pp + Annexes.

Floury, M., Delattre, C., Ormerod, S.J., Souchon, Y., 2012. Global versus local change effects on a large European river. Sci. Total Environ. 441:220-229. https://doi.org/10.1016/j. scitotenv.2012.09.051. 
Garnier, J., Billen, G., 1993. Ecological interactions in a shallow sand-pit lake (Créteil Lake, France). A modelling approach. Nutrient Dynamics and Biological Structure in Shallow Freshwater and Brackish Lakes. Hydrobiologia 275/276, pp. 97-114.

Garnier, J., Billen, G., Allardi, J., Servais, P., 1991. La Seine, un écosystème fragile. Référence La Recherche 22 (228), 106-108.

Garnier, J., Billen, G., Coste, M., 1995. Seasonal succession of diatoms and chlorophyecae in the drainage network of the river seine: observations and modelling. Limnol Oceanogr. 40, 750-765.

Garnier, J., Billen, G., Levassor, A., 1998. Fonctionnement et impacts écologiques des réservoirs de Champagne. Chapitre 6. In: Meybeck, M., De Marsily, G., Fustec, F. (Eds.), La Seine en son bassin. Fonctionnement écologique d'un système fluvial anthropisé. Elsevier, Paris, pp. 263-300.

Garnier, J., Billen, G., Palfner, L., 2000. Understanding the oxygen budget of the Mosel drainage network with the concept of heterotrophic/autotrophic sequences: the Riverstrahler approach. Hydrobiologia 410, 151-166.

Garnier, J., Billen, G., Hannon, E., Fonbonne, S., Videnina, Y., Soulie, 2002. Modeling transfer and retention of nutrients in the drainage network of the Danube River. Estuar. Coast. Shelf Sci. 54, 285-308.

Garnier, J., Anglade, J., Benoit, M., Billen, G., Puech, T., Ramarson, A., Passy, P., Silvestre, M. Lassaletta, L., Trommenschlager, J.-M., Schott, C., Tallec, G., 2016. Reconnecting crop and cattle farming to reduce nitrogen losses in river water of an intensive agricultura catchment (Seine basin, France). Environ. Sci. Pol. 63:76-90. https://doi.org/10.1016/ j.envsci.2016.04.019.

Garnier, J., Ramarson, A., Thieu, V., Némery, J., Théry, S., Billen, G., Coynel, A., 2018. How can we improve water quality when the urban waste water directive has been complied (the case of the Lot River)? Environ. Sci. Pollut. Res. https://doi.org/10.1007/ s11356-018-1428-1.

Grizzetti, B., Bouraoui, F., Aloe, A., 2012. Changes of nitrogen and phosphorus loads to European seas. Glob. Chang. Biol. https://doi.org/10.1111/j.1365-2486.2011.02576.x.

Gu, S., Gruau, G., Dupas, R., Rumpel, C., Crème, A., Fovet, O., Gascuel-Odoux, C., Jeanneau, L., Humbert, G., Petitjean, P., 2017. Release of dissolved phosphorus from riparian wetlands: evidence forcomplex interactions among hydroclimate variability, topography and soil properties. Sci. Total Environ. 598, 421-431.

Heisler, J., Glibert, P.M., Burkholder, J.M., Anderson, D.M., Cochlan, W., Dennison, W.C. Dortch, Q., Gobler, C.J., Heil, C.A., Humphries, E., Lewitus, A., Magnien, R., Marshall H.G., Sellner, K., Stockwell, D.A., Stoecker, D.K., Suddleson, M., 2008. Eutrophication and harmful algal blooms: a scientific consensus. Harmful Algae 8, 3-13.

Howarth, R., Chan, F., Conley, D.J., Garnier, J., Doney, S.C., Marino, R., Billen, G., 2011 Coupled biogeochemical cycles: eutrophication and hypoxia in temperate estuaries and coastal marine ecosystems. Front. Ecol. Environ. 9:18e26. https://doi.org/ $10.1890 / 100008$.

James, C., Fisher, J., Russel, V., Collings, S., Moss, B., 2005. Nitrate availability and hydrophyte species richness in shallow lakes. Freshw. Biol. 50:1049-1063. https://doi. org/10.1111/j.1365-2427.2005.01375.x.

Jarvie, H.P., Smith, D.R., Norton, L.R., Edwards, F.K., Bowes, M.J., King, S.M., Scarlett, P., Davies, S., Dils, R.M., Bachiller-Jareno, N., 2018. Phosphorus and nitrogen limitation and impairment of headwaterstreams relative to rivers in Great Britain: a nationa perspective on eutrophication. Sci. Total Environ. 621, 849-862.

Justes, E., Beaudoin, N., Bertuzzi, P., Charles, R., Constantin, J., Durr, C., Hermon, C. Joannon, A., Le Bas, C., Mary, B., Mignolet, C., Montfort, F., Ruiz, L., Sarthou, J.-P., Souchere, V., Tournebize, J., Savini, I., Rechauchère, O., 2012. Réduire Les Fuites de Nitrate Au Moyennde Cultures intermédiaires: conséquences Sur Les Bilans d'eau et d'azote, Autres Services écosystémiques. Expertise collective INRA, France, p. 60.

Justić, D., Rabalais, N.N., Turner, R.E., 1995. Stoichiometric nutrient balance and origin of coastal eutrophication. Mar. Pollut. Bull. 30:41-46. https://doi.org/10.1016/0025326X(94)00105-I.

Kirkby, M.J., Jones, R.J.A., Irvine, B., Gobin, A., Govers, G., Cerdan, O., AJJ, Van Rompaey, Le Bissonnais, Y., Daroussin, J., King, D., Montanarella, L., Grimm, M., Vieillefont, V., Puigdefabregas, J., Boer, M., Kosmas, C., Yassoglou, N., Tsara, M., Mantel, S., Van Lynden, G.J., Huting, J., 2004. Pan-European soil erosion risk assessment: the PESERA map. Version 1 October 2003. Explanation of Special Publication Ispra 2004 No.73 (S.P.I.04.73). European Soil Bureau Research Report No.16, EUR 21176. Office for Official Publications of the European Communities, Luxembourg (18 pp.).

Lancelot, C., Veth, C., Mathot, S., 1991. Modelling ice edge phytoplankton bloom in the Scotia-Weddell Sea sector of the Southern Ocean during spring 1988. J. Mar. Syst. 2, 333-346.

Lancelot, C., Thieu, V., Polard, A., Garnier, J., Billen, G., Hecq, W., Gypens, N., 2011. Ecological and economic effectiveness of nutrient reduction policies on coastal Phaeocystis colony blooms in the southern North Sea: an integrated modeling approach. Sci. Total Environ. 409, 2179-2191.

Lassaletta, L., Billen, G., Grizzetti, B., Anglade, J., Garnier, J., 2014. 50 year trends in nitrogen use efficiency of world cropping systems: the relationship between yield and nitrogen input to cropland. Environ. Res. Lett. 9. https://doi.org/10.1088/1748-9326/9/ 10/105011.

Latapie, A., Camenen, B., Rodrigues, S., Paquier, A., Bouchard, J.P., Moatar, F., 2014 Assessing channel response of a long river influenced by human disturbance. Catena $121,1-12$.

Latour, D., Sabido, O., Salençon, M.-J., Giraudet, H., 2004. Dynamics and metabolic activity of the benthic cyanobacterium Microcystis aeruginosa in the Grangent reservoi (France). J. Plankton Res. 26 (7):719-726 (1 July 2004). https://doi.org/10.1093/ plankt/fbh075.

Le Noë, J., Billen, G., Garnier, J., 2017. Nitrogen, phosphorus and carbon fluxes through the French Agro-Food System: an application of the GRAFS approach at the territorial scale. Sci. Total Environ. https://doi.org/10.1016/j.scitotenv.2017.02.040.

Le, T.P.Q., Billen, G., Garnier, J., Théry, S., Ruelland, D., Nguyem, X.A., Chau, V.M., 2010. Modelling nutrient transfer in the sub-tropical Red River system (China and
Vietnam): implementation of the Seneque/Riverstrahler model. J. Asia Earth Sci. 37. 259-274

Le, T.P.Q., Billen, G., Garnier, J., 2014. Long-term evolution of the biogeochemical functioning of the Red River (Vietnam): past and present situations. REC. https://doi.org/ 10.1007/s10113-014-0646-4.

Loos, S., Middelkoop, H., van der Perk, M., van Beek, R., 2009. Large scale nutrient modelling using globally available datasets: a test for the Rhine basin. J. Hydrol. 369: 403-415. https://doi.org/10.1016/j.jhydrol.2009.02.019.

Lyne, V., Hollick, M., 1979. Stochastic time-variable rainfall-runoff modelling. Hydrology and Water Resources. Symposium. Institution of Engineers, Perth, Australia.

Malagó, A., Bouraoui, F., Vigiak, O., Grizzetti, B., Pastori, M., 2017. Modelling water and nutrient fluxes in the Danube River Basin with SWAT. Sci. Total Environ. 603-604: 196-218. https://doi.org/10.1016/j.scitotenv.2017.05.242.

Meybeck, M., 1986. Composition chimique des ruisseaux non pollués de France. Sci. Géol. Bull. 39, 3-77.

Minaudo, C., Meybeck, M., Moatar, F., Gassama, N., Curie, F., 2015. Eutrophication mitigation in rivers: 30 years of trends in spatial and seasonal patterns of biogeochemistry of the Loire River (1980-2012). Biogeosciences 12:2549-2563. https://doi.org/ 10.5194/bg-12-2549-2015.

Minaudo, C., Moatar, F., Coynel, A., Etcheber, H., Gassama, N., Curie, F., 2016. Using recent high-frequency surveys to reconstitute 35 years of organic carbon variations in a eutrophic lowland river. Environ. Monit. Assess. 188 (41). https://doi.org/10.1007/ s10661-015-5054-9.

Minaudo, C., Curie, F., Jullian, Y., Gassama, N., Moatar, F., 2018. QUAL-NET, a high temporal resolution eutrophication model in large hydrographic networks. Biogeosciences 15: 2251-2269. https://doi.org/10.5194/bg-15-2251-2018.

Moatar, F., Gailhard, J., 2006. Water temperature behaviour in the River Loire since 1976 and 1881. Compt. Rendus Geosci. 338, 319-328.

Moatar, F., Meybeck, M., 2005. Compared performances of different algorithms for estimating annual nutrient loads discharged by the eutrophic River Loire. Hydrol. Process. 19 (2), 429-444.

Moatar, F., Fessant, F., Poirel, A., 1999. pH modelling by neural networks. Application of control and validation data series in the Middle Loire river. Ecol. Model. 120 (2-3), $141-156$

Moatar, F., Miquel, J., Poirel, A., 2001. A quality-control method for physical and chemical monitoring data. Application to dissolved oxygen levels in the river Loire (France). J. Hydrol. 252 (1-4), 25-36.

Moatar, F., Ducharne, A., Thiéry, D., Bustillo, V., Sauquet, E., Vidal, J.P., 2010. La Loire à l'épreuve du changement climatique. Géosciences 12, 78-87.

Official Journal of the European Union Regulation, 2012. No 259/2012 the European parliament and the council of 14 March 2012, amending Regulation (EC) No 648/ 2004 as regards the use of phosphates and other phosphorus compounds in consumer laundry detergents and consumer automatic dishwasher detergents. http://eur-lex.europa.eu/legal-content/EN/ALL/?uri=CELEX:32012R0259 (last accessed, 3 May 2014)

Ouzeau, G., Déqué, M., Jouini, M., Planton, S., Vautard, R., 2014. Le climat de la France au XXIe siècle Volume 4. Scénarios régionalisés, édition 2014 pour la métropole et les régions d'outre-mer. RA. Direction générale de l'Energie et du climat. Ministère de l'Écologie, du Développement durable et de l'Énergie. www.developpementdurable.gouv.fr (64 pp.).

Passy, P., Gypens, N., Billen, G., Garnier, J., Lancelot, C., Thieu, V., Rousseau, V., Callens, J., 2013. A model reconstruction of riverine nutrient fluxes and eutrophication in the Belgian coastal zone since 1984. J. Mar. Syst. 128, 106-122.

Passy, P., Le Gendre, R., Garnier, J., Cugier, P., Callens, J., Paris, F., Billen, G., Riou, P., Romero, E., 2016. Eutrophication modelling chain for improved management strategies to prevent algal blooms in the Seine Bight. Mar. Ecol. Prog. Ser. https://doi.org/10.3354/ meps11533.

Poisvert, C., Curie, F., Moatar, F., 2017. Annual agricultural N surplus in France over a 70year period. Nutr. Cycl. Agroecosyst. 107 (1):63-78. https://doi.org/10.1016/j. jmarsys.2013.05.005.

Raimonet, M., Thieu, V., Silvestre, M., Oudin, L., Rabouille, C., Vautard, R., Garnier, J., 2018. Coastal eutrophication potential under future climate change: a landward perspective. Front. Mar. Sci. https://doi.org/10.3389/fmars.2018.00136.

Redfield, A.C., Ketchum, B.H., Richards, F.A., 1963. The influence of organisms on the composition of sea-water. In: Hill, M.N. (Ed.), The Sea. John Wiley, New York, pp. $12-37$

Romero, E., Garnier, J., Lassaletta, L., Billen, G., Le Gendre, R., Riou, P., Cugier, P., 2013. Large-scale patterns of river inputs in SW Europe: seasonal and interannual variations and potential eutrophication effects at the coastal zone. Biogeochemistry 113 : 481-505. https://doi.org/10.1007/s10533-012-9778-0.

Ruelland, D., Billen, G., Brunstein, D., Garnier, J., 2007. SENEQUE: a multi-scaled GIS interface to the RIVERSTRAHLER model of the biogeochemical functioning of river systems. Sci. Total Environ. 375, 257-273.

Sabater, S., Artigas, J., Durán, C., Pardos, M., Romaní, A.M., Tornés, E., Ylla, I., 2008. Longitudinal development of chlorophyll and phytoplanktonassemblages in a regulated large river (the Ebro River). Sci. Total Environ. 404 (1), 196-206.

Sferratore, A., Billen, G., Garnier, J., Smedberg, E., Humborg, C., Rahm, L., 2008. Modelling nutrient fluxes from sub-arctic basins: comparison of pristine vs. dammed rivers. J. Mar. Syst. 73, 236-249.

Solagro, 2014. Afterres 2050: Un scénario soutenable pour l'agriculture et l'utilisation des terres en France à l'horizon 2050. http://www.solagro.org/site/393.html.

Thiéry, D., 2018. Logiciel ÉROS version 7.1. Guide d'utilisation. Rapport BRGM/RP67704-FR.

Thieu, V., Billen, G., Garnier, J., 2009. Nutrient transfer in three contrasting NW European watersheds: the Seine, Somme, and Scheldt Rivers. A comparative application of the Seneque/Riverstrahler model. Water Res. 43, 1740-1748. 
Thieu, V., Garnier, J., Billen, G., 2010. Assessing impact of nutrients mitigation measure along rivers continuum to southern bight of the North Sea. Sci. Total Environ. 408, $1245-1255$.

Tilman, D., Kilham, S.S., Kilham, P., 1982. Phytoplankton community ecology: the role of limiting nutrients. Annu. Rev. Ecol. Syst. 13, 349-372.

Toth, G., Jones, A., Montanarella, L., 2013. LUCAS topsoil survey. Methodology, Data and Results. JRC Technical Reports. Publications Office of the European Union, Luxembourg (EUR 26102, Scientific and Technical Research Series. ISSN 1831-9424 (online); ISBN 978-92-79-32542-7). https://doi.org/10.2788/97922.

UWWTD EU directive (Urban wastewater treatment Directive), 1991. 91/271/CEE du Conseil, du 21 mai 1991, relative au traitement des eaux urbaines résiduaires, JO L 135 du 30.5.1991. pp. 40-52.

Venohr, M., Hirt, U., Hofmann, J., Opitz, D., Gericke, A., Wetzig, A., Natho, S., Neumann, F., Hürdler, J., Matranga, M., Mahnkopf, J., Gadegast, M., Behrendt, H., 2011. Modelling of nutrient emissions in river systems - MONERIS - methods and background. Int. Rev. Hydrobiol. 96:435-483. https://doi.org/10.1002/iroh.201111331.

Viaroli, P., Bartoli, M., Giordani, G., Naldi, M., Orfandini, S., Zaldivar, J.M., 2008. Community shifts, alternative stable states, biogeochemical controls and feedbacks in eutrophic coastal lagoons: a brief overview. Aquat. Conserv. Mar. Freshwat. Ecosyst. 18, S105-S117.

Wasson, J.G., Chandesris, A., Pella, H., Blanc, L., 2004. Les Hydro-écorégions : une approche fonctionnelle de la typologie des rivières pour la Directive Cadre Européenne sur l'Eau. Ingénieries - Eau Agriculture Territoires 40, 3-10.

Wellen, C., Kamran-Disfani, A.-R., Arhonditsis, G.B., 2015. Evaluation of the current state of distributed watershed nutrient water quality modeling. Environ. Sci. Technol. 49: 3278-3290. https://doi.org/10.1021/es5049557.

WFD (Water Framework Directive), 2000. Directive 2000/60/EC of the European Parliament and of the Council of 23 October 2000. OLJ 327/1, 22.12. pp. 1-72. 